\title{
Damian MRUGALSKI OP*
}

\section{NIESKOŃCZONOŚĆ BOGA U ORYGENESA: PRZYCZYNA WIELKIEGO NIEPOROZUMIENIA}

Zdarza się niekiedy, że pewne opinie wybitnych i znanych uczonych wpływają na poglądy kolejnych badaczy do tego stopnia, iż przez dziesięciolecia powtarza się i utrwala tezy, które są błędne. Tak też się stało z konceptem nieskończoności Boga w pierwszych wiekach chrześcijaństwa. Idea ta pojawiła się w dyskursie filozoficznym już na samym początku spotkania filozofii greckiej z Objawieniem, a więc na początku naszej ery. Jednak do dzisiaj wielu historyków filozofii i teologii powtarza nadal tezę, iż pierwszym myślicielem, który w pozytywny sposób mówił o nieskończoności Boga był dopiero Plotyn - pogański filozof żyjący w połowie III w. po Chrystusie. Mało tego, wielu twierdzi, że to właśnie w oparciu o rozstrzygnięcia Plotyna chrześcijaństwo zbudowało swą doktrynę o Bogu nieskończonym. W niniejszym artykule przedstawimy powody, dla których współcześni badacze wciąż powielają i przez to utrwalają ów błędny pogląd. Będziemy starali się również wykazać, iż Orygenes, który zakończył swój żywot piętnaście lat przed śmiercią Plotyna, podzielał myśl swoich żydowskich i chrześcijańskich poprzedników, którzy dowodzili, iż Bóg jest nieskończony w swej naturze i mocy, co wcale nie umniejsza, lecz jeszcze bardziej podkreśla, Boską dobroć i doskonałość.

1. Historycy idei o nieskończoności Boga. Co do tego, że termin ö $\pi \varepsilon ı \rho o v$ („,nieskończoność” lub „,bezkres”) w filozofii greckiej przed Chrystusem posiadał przeważnie negatywne konotacje, panuje wśród współczesnych historyków idei powszechna zgoda. Coś, co nie ma końca ( $\pi \varepsilon ́ \rho \varsigma \varsigma$ ) - sądzili myśliciele greccy - jest „nie-dokończone”, „nie-określone”, a więc i „niedoskonałe”.

* Dr Damian Mrugalski OP - wykładowca patrologii, historii filozofii starożytnej i języka greckiego w Kolegium Filozoficzno-Teologicznym Polskiej Prowincji Dominikanów w Krakowie; e-mail: mnichop@gmail.com.

${ }^{1}$ Oczywiście pojawiali się w historii filozofii presokratejskiej myśliciele, jak Anaksymander czy Anaksagoras, którzy posługiwali się pojęciem ö́rııov w odniesieniu do Prazasady, lecz ich zamierzeniem było raczej odróżnienie się od tez stawianych przez swoich poprzedników, którzy sądzili, iż przyczyną powstania świata jest ściśle określony element materialny, jak woda, ziemia

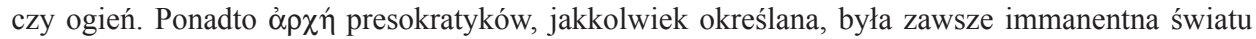
i w jakiś sposób materialna, nawet wówczas, gdy nie była identyfikowana z jakimś określonym 
Konsekwentnie, również słowo $\pi \varepsilon ́ p \alpha \varsigma$ oznaczało dla Greków nie tylko „kres”, czy „granicę”, ale i „doskonałość” jakiejś rzeczy². Platon łączył pojęcie apeironu $\mathrm{z}$ niezdeterminowaną i bezkresną materią, w odróżnieniu od ściśle określonych i posiadających granice idei. Uznanie rzeczywistości boskiej za nieskończoną byłoby więc dla platonika po prostu absurdem, co zauważa oksfordzki historyk idei Charles Bigg: „Cóż za absurdalnym, oprócz tego że krzywdzącym, słowem jest «nieskończony», całkowicie materialnym we wszystkich swych skojarzeniach, i jakby nic niemówiącym gdy się je zastosuje do ducha, podobnie jak słowa «bezbarwny» i «nieuchwytny». Mimo to, jest ono powszechnie używane, jak gdyby było najwyższym określeniem czci. Dla Platonika «nieskończony» oznacza prawie to samo, co «zły». Ograniczenie natomiast należy do natury prawdy i piękna"3.

Powyższa teza byłaby zapewne prawdziwa, gdyby angielski uczony nie utożsamiał słowa „Platonik” z osobą Adamancjusza, co niestety uczynił. W rzeczywistości bowiem, cytowany tekst jest jego komentarzem do fragmentu z De principiis (II 9, 1). Platonik Orygenes - wyjaśnia więc nasz autor przyjmuje, iż „Bóg jest doskonale mądry, doskonale sprawiedliwy, doskonale mocny; ale doskonałość tych atrybutów polega dokładnie na tym, że są one ograniczone jeden przez drugi"4. O tym, czy doskonałość w doktrynie Orygenesa rzeczywiście oznacza bycie ograniczonym, powiemy w dalszej części artykułu. Przytoczyliśmy tu jednak wypowiedź angielskiego badacza z końca XIX w. z dwóch powodów. Po pierwsze dlatego, iż w wyjaśnieniu kontrowersyjnego fragmentu tekstu Orygenesa, którego głównym tematem jest nie natura Boga, lecz skończoność stworzeń i skończona liczba bytów stworzonych przez Boga, narzuca on pewną platońską kalkę interpretacyjną. W ten sposób stara się rozwiązać aporię pojawiającą się w związku z brakiem jednoznacznych wypowiedzi Aleksandryjczyka na temat nieskończoności Boga. Po drugie, po upływie prawie wieku na tezę oksfordzkiego uczonego powołuje się w swym komentarzu do edycji krytycznej tekstu $O$ zasadach dwóch znamienitych patrologów: Henri Crouzel i Manlio Simonetti ${ }^{5}$. Niestety również oni, choć wskazują, iż zarówno greckie, jak i łacińskie fragmenty De principiis (II $9,1)$ są wybrakowane i mało wiarygodne, konkludują ostatecznie swoje obserwacje w sposób nie wiele odbiegający od wspomnianej tezy Bigga. Po stwierdzeniu, iż koncept nieskończoności w filozofii greckiej był w przeważającej

pierwiastkiem materii. W każdym razie żaden z presokratyków nie dochodzi do pozytywnego stwierdzenia, iż w transcendentnym i niecielesnym Bogu tkwi nieskończona moc. Por. G. Reale,

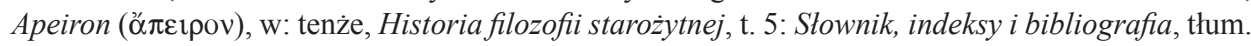
E.I. Zieliński, Lublin 2002, 29.

${ }^{2}$ Por. Liddell - Scott, s. 1365.

${ }^{3}$ C. Bigg, The Christian Platonists of Alexandria. Eight Lectures Preached Before the University of Oxford in the Year 1886, Oxford 1886, 159, nota 2, thum. własne.

${ }^{4}$ Tamże, tłum. własne.

${ }^{5}$ Por. H. Crouzel - M. Simonetti, nota 2, w: Origène, Traité des principes, t. 2: Commentaire et fragments, SCh 253, Paris 1978, 213. 
mierze uważany za negatywny, dodają: „Przeciwnie do tej tendencji, Plotyn dowartościuje ideę nieskończoności Boga rozumianą jako pełnię, a nie jako prywację bytu. Orygenes natomiast pozostaje przy opinii helleńskiej: skończoność mocy Boga jest wymogiem Jego własnej doskonałości”.

Po latach, Simonetti powtórzy powyższą tezę w słowniku pojęć i zagadnień orygeniańskich ${ }^{7}$, przez co będzie ona powielana w różnych publikacjach, nawet tych, które nie dotyczą doktryny samego Adamancjusza, lecz ogólnie różnych konceptów i tendencji myślowych obecnych w filozofii i teologii starożytnej. Dla przykładu, Claudio Moreschini, wybitny znawca myśli Ojców Kapadockich, pisząc o koncepcji nieskończoności Boga u Grzegorza z Nyssy, stwierdza: „Niemożliwość poznania Boga, według Nysseńczyka, zależy przede wszystkim od Jego nieskończoności. Intelekt ludzki, który porusza się zawsze w obrębie tego, co przestrzenne, nie może zrozumieć natury, która nie ma rozmiarów ani ograniczeń czy to w przestrzeni czy w czasie (wieczność). Również Plotyn utrzymywał, że niepoznawalność Boga jest wynikiem Jego nieskończoności [...]. Nysseńczyk jednak dochodzi do takiej konkluzji przemierzając bardzo określoną drogę o charakterze racjonalnym, przeciwstawiając się pewnym tendencjom obecnym w filozofii greckiej, zgodnie z którymi nieskończoność posiada jedynie znaczenie negatywne. Owo wahanie wyraża również Orygenes, który odrzucił twierdzenie, iż Bóg mógłby być z pewnością nieskończony"

Warto zauważyć, że choć Moreschini mówi o wahaniu się (titubanza) Orygenesa w kwestii nieskończoności, sam stwierdza jednak, że według Aleksandryjczyka Bóg ,z pewnością” nie mógłby być nieskończony. Ponieważ włoski uczony nie zna żadnego tekstu (i nie może znać, gdyż takowy nie istnieje), w którym Adamancjusz negowałby nieskończoność Bożej natury, dodaje owo ,z pewnością" (senz'altro), jak gdyby chciał osłabić wydźwięk swojej tezy. W każdym razie, wypowiedź Moreschiniego nie jest oparta na rzetelnej

\footnotetext{
${ }^{6}$ Tamże, tłum. własne.
}

${ }^{7}$ Por. M. Simonetti, Dio (Padre), w: Origene. Dizionario. La cultura, il pensiero, le opere, ed. A. Monaci Castagno, Roma 2000, 120, tłum. własne: „Zakres aktywności stwórczej Boga jest jednak ograniczony. Stworzył On bowiem skończoną liczbę stworzeń racjonalnych «ponieważ gdzie nie ma końca, tam nie ma możliwości zrozumienia i określenia» (De principiis II 9, 1; IV 4, 8). To, co jest nieskończone jest niepoznawalne (Commentarius in Matthaeum XIII 1). W rzeczywistości Orygenes podziela negatywne rozumienie «nieskończoności» («nieokreśloności»), które było charakterystyczną cechą filozofii greckiej przed Plotynem".

${ }^{8}$ C. Moreschini, I Padri cappadoci. Storia, letteratura, teologia, Roma 2008, 171, thum. własne. Podobnego zdania jest M. Przyszychowska (Wstęp, w: Grzegorz z Nyssy, O stworzeniu człowieka, ŹMT 39, Kraków 2006, 28), polska tłumaczka i komentatorka dzieł Grzegorza z Nyssy, która pisząc o koncepcie nieskończoności Boga u Nysseńczyka zauważa: „Jego teoria podważa wielowiekową tradycję filozoficzną, która aż do Plotyna uznawała za coś wręcz oczywistego, że dobro (to co doskonałe) jest ograniczone, a zło (niedoskonałe) nieograniczone. Zresztą Grzegorz miał tu na uwadze nie tylko filozofów, ale także Orygenesa. Ten ostatni twierdził, że moc Boża jest ograniczona, dlatego powstała ograniczona liczba stworzeń, czyli tylko tyle, o ile Bóg jest w stanie się zatroszczyć”. 
analizie tekstów źródłowych, lecz na pewnym powszechnym, funkcjonującym w literaturze patrystycznej, przekonaniu'. Negowanie istnienia konceptu nieskończoności Boga przed pojawieniem się neoplatonizmu, sprawia, iż niezrozumiałą staje się późniejsza argumentacja Ojców Kościoła, jak chociażby wspomnianego wyżej Grzegorza z Nyssy, który budując swoją doktrynę o Bogu nieskończonym, opierał się nie tyle na Plotynie, co właśnie na Filonie z Aleksandrii, Klemensie i Orygenesie. Brak wnikliwych analiz dotyczących początków interesującego nas zagadnienia sprawia, iż badacze teologii patrystycznej powstałej po III w. dochodzą do błędnych wniosków lub powtarzają niemniej błędne, chociaż ugruntowane już tezy. Podobnie wygląda sprawa w kręgu historyków filozofii pogańskiej. Ci jednak z nich, którzy zapoznali się z myślą religijną pierwszych wieków, są w stanie dostrzec, że przed Plotynem, uważanym powszechnie za „odkrywcę” pozytywnego konceptu nieskończoności, byli pewni myśliciele, którzy wspominali o nieskończoności Boga. Przykładem może tu być Giovanni Reale, który w swej wielotomowej Historii filozofii starożytnej, w rozdziale poświęconym nieskończoności Plotyńskiego Jedna stwierdza: ,Jest to nowa koncepcja transcendencji, która w kręgu myśli greckiej miała tylko bardzo ogólnikowe antecedensy, natomiast jest wyraźnie obecna u Filona z Aleksandrii. Najwyższa zasada transcenduje nie tylko świat fizyczny, lecz także każdą postać skończoności, również tę skończoność, w której Platon i Arystoteles uwięzili to co inteligibilne i sam Umysł. Zrozumiałe jest więc, dlaczego Plotyn podaje zwykle negatywne określenia Jednego (skoro bowiem Jedno jest nieskończone, nie odnosi się do niego żadne ze skończonych określeń, bo wszystkie one są od niego późniejsze) i głosi wręcz, że Jedno jest niewysłowione"

Autor cytowanego tekstu wspomina wprawdzie, że już Filon z Aleksandrii, któremu w swym dziele poświęcił cały rozdział, mówił wyraźnie o Bogu transcendentnym - niewyczerpanym źródle nieskończonej mocy, lecz ostatecznie oryginalność w opisaniu konceptu pozytywnie rozumianej nieskończoności przypisuje Plotynowi. Nie wspomina nic o Klemensie Aleksandryjskim, u którego, co pokażemy niżej, znajdujemy definicję Boga jako nieskończonego Jedna (teza, którą powtórzy Plotyn), ani o Orygenesie, który znał

\footnotetext{
${ }^{9}$ Nie chciałbym przypisywać ignorancji temu wybitnemu badaczowi odnośnie do doktryny Orygenesa, której przecież w licznych monografiach patrystycznych poświęcił wiele miejsca. W kwestii nieskończoności Boga jednakże Moreschini powtarza utarte już od lat poglądy, bez ich weryfikacji. Widać to również w jego dziele: Storia della filosofia patristica (Brescia 2005, 136), gdzie stwierdza, że moc Boga, według Orygenesa, jest „,ograniczona i nie nieskończona”, po czym wskazuje na fragmenty z De principiis, przytaczane również przez Simonettiego, nie dokonując żadnej głębszej analizy tych tekstów. Swój pogląd w tej kwestii koryguje nieco w: Storia del pensiero cristiano tardo-antico (Milano 2013, 382-383), gdzie przyznaje, iż u Orygenesa można znaleźć pewne wątki związane z nieskończonością Boga, lecz ostatecznie ogranicza je jedynie do kwestii Bożej nieskończoności w czasie, a więc do konceptu „wieczności”.

${ }^{10}$ G. Reale, Historia filozofii starożytnej, t. 4: Szkoły epoki cesarstwa, tłum. E.I. Zieliński, Lublin 1999, 517.
} 
myśl Filona i Klemensa, i bynajmniej z nią nie polemizowa ${ }^{11}$. U wszystkich tych autorów: żydowskich i chrześcijańskich znajdujemy również całą gamę negatywnych określeń Boga, o których wspomina Reale, przy okazji prezentacji doktryny Plotyna. Również oni uważają, że Bóg jest nieskończenie różny od skończonych stworzeń oraz że transcenduje nawet to, co inteligibilne. Tezy historyków filozofii starożytnej na temat odkrycia konceptu nieskończoności Boga byłyby inne, gdyby odważyli się oni prześledzić, oprócz doktryn filozofów pogańskich, również linię genetycznego rozwoju myśli chrześcijańskiej przed Plotynem. Wówczas mogłoby się okazać, że to nie chrześcijaństwo przejęło od Plotyna ideę Boga nieskończonego w swej naturze i mocy, a przez to niewyrażalnego, lecz że to Plotyn zbudował swą koncepcję w oparciu o filozofię żydowską i chrześcijańską, która rozwijała się w jego mieście już na trzy wieki przed powstaniem Ennead.

Na koniec tego paragrafu chciałbym wspomnieć o jeszcze jednym ważnym historyku idei, a mianowicie o Rudolfie Mondolfo, którego monumentalne dzieło o nieskończoności w filozofii starożytnej, ignorowane przez większość współczesnych badaczy, zainspirowało mnie do przeprowadzenia niniejszych badań. Po przeanalizowaniu różnych znaczeń idei nieskończoności w myśli starożytnych (od Homera aż do epikurejczyków), w rozdziale poświęconym Filonowi i neoplatonikom, włoski filozof stwierdza: „Cała spekulacja, o charakterze specyficznie religijnym, ostatnich wieków hellenizmu, od Judeo-Aleksandryjczyków aż do neoplatoników, koncentruje się przede wszystkim (lub wyłącznie) na nieskończoności Bożej, całkowicie duchowej. Nie zajmuje się natomiast nieskończonością materii. A jeśli już to czyni, to tylko $\mathrm{w}$ tym celu, aby ukazać ją jako derywat lub niezbędną antytezę Boskiej Zasady. Częściej jednak, antyteza, mając wskazywać na niższość świata i jego dewaluację, prowadzi do przeciwstawienia nieskończoności Bożej (znaku doskonałości) skończoności kosmosu"12.

Choć w swej monografii Mondolfo nie zajmuje się konceptem nieskończoności u myślicieli chrześcijańskich pierwszych wieków (podaje jedynie kilka przykładowych odnośników do dzieł Filona i medioplatoników), cytowana powyżej opinia jest jak najbardziej prawdziwa również jeśli chodzi o filozofię

${ }^{11}$ Również A. Baron (Neoplatońska idea Boga a ewangelizacja. Analiza anonimowego Komentarza do „Parmenidesa” Platona na tle myśli plotyńsko-porfiriańskiej, Kraków 2005, 146), przytaczając opinię G. Realego oraz odpowiednie teksty Plotyna mówiące o nieskończoności Jednego, stwierdza: „W ten sposób Plotyn zrywa z tradycyjną filozofią grecką, zgodnie z którą doskonałość łączyła się z tym, co określone, skończone, i przygotowuje grunt pod nowe ukierunkowanie pojmowania Boga, które podejmie między innymi teologia chrześcijańska".

${ }^{12}$ R. Mondolfo, L'infinito nel pensiero dell'antichità classica, Milano 2012, 519, thum. własne. Choć cytuję w tym miejscu tekst $\mathrm{z}$ wznowionego wydania, dzieło włoskiego uczonego ukazało się w 1. poł. XX w. i było zatytułowane: L’infinito nel pensiero dei Greci, Firenze 1934. Na to właśnie wydanie powołują się również Crouzel i Simonetti, w swym komentarzu do De Principiis Orygenesa (SCh 253,213), lecz poza stwierdzeniem, iż „koncept nieskończoności nie zawsze był uznawany przez Greków za negatywny”, nie wyciągają z tej pozycji istotnych wniosków. 
Ojców Kościoła żyjących przed Plotynem. Niezależnie od tego, czy uznawali oni istnienie nieskończonej preegzystującej materii, czy też przyjmowali koncepcję creatio ex nihilo, uznawali Boga jako transcendentną i nieskończoną pod względem natury i mocy Zasadę wszystkiego. Jeśli mówili, tak jak to czynił Orygenes, o skończoności świata, czy też o skończonej liczbie stworzeń, które stworzył Bóg, to tylko dlatego, aby uwypuklić, a nie zanegować, doskonałość i nieskończoność Boga, obok którego nie może istnieć żadna inna nieskończoność. To od momentu spotkania filozofii greckiej z Biblią, a nie od pojawienia się systemu Plotyna, nieskończoność staje się atrybutem pozytywnym i specyficznie boskim. W kolejnych paragrafach postaram się więc wykazać, iż wyrażona wyżej intuicja włoskiego uczonego, ma swoje potwierdzenie w zachowanych tekstach źródłowych.

2. Poprzednicy Orygenesa o nieskończoności: Filon i Klemens z Aleksandrii ${ }^{13}$. Pojawienie się pozytywnie rozumianego konceptu nieskończoności Boga było konsekwencją spotkania filozofii greckiej z Biblia, które dokonało się na początku naszej ery, a może nawet nieco wcześniej. W rzeczywistości bowiem myśliciele żydowscy jak i chrześcijańscy, nie mogli nie włączyć do dyskursu filozoficznego niezwykle istotnej przesłanki Objawienia, jaką była swoiście rozumiana idea opatrzności wyrażająca się w Bożej trosce o dzieje konkretnego ludu, a nawet o losy poszczególnych jednostek. To właśnie ta nowa wizja Boga zaangażowanego w historię, w połączeniu $\mathrm{z}$ konceptem Jego transcendencji i niezmienności, doprowadziły do filozoficznej konstatacji, iż Bóg jest niewyczerpanym Dobrem, które udziela się swemu stworzeniu nieustannie i na nieskończoną ilość sposobów, a przy tym nic nie traci ze swej doskonałości. Nieskończoność nie oznacza już odtąd jakiegoś braku związanego z byciem „nie-dokończonym”, a więc „nie-doskonałym”, lecz wskazuje na transcendentną ,nad-obfitość", z której wypływają nieskończone dobrodziejstwa ${ }^{14}$. Pierwszą filozoficzną refleksję o tak pojmowanej nieskończoności znajdujemy u Filona z Aleksandrii:

${ }^{13}$ Ponieważ o doktrynie transcendencji Boga u Filona i Klemensa oraz o jej filozoficznych źródłach pisaliśmy już obszernie gdzie indziej (zob. D. Mrugalski, Il Dio trascendente nella filosofia alessandrina giudaica e cristiana. Filone e Clemente, Roma 2013), w tym miejscu przejdziemy bezpośrednio do omówienia interesującego nas zagadnienia nieskończoności, o którym tam jedynie wspomnieliśmy. Pragniemy jednakże zaznaczyć, że niektóre teksty źródłowe, cytowane w naszej poprzedniej pracy, znajdą się również w obecnym tekście, choć będą one analizowane pod innym kątem.

${ }^{14}$ Połączenie konceptu doskonałości ze skończonością mogło logicznie tłumaczyć przypadek Boga, który nie interesuje się światem, jak na przykład Pierwszy Nieruchomy Poruszyciel w systemie Arystotelesa. Mogło się też sprawdzać w doktrynie Platona, gdzie Bóg (idea Dobra) jest miarą wszystkiego, co istnieje, albo też (jeśli Demiurga z Timajosa uznamy za Boga Platona), gdzie Bóg wprowadza jedynie ład i harmonię w świecie, który tworzy na podstawie doskonale skończonego świata idei. Doskonałość rozumiana jako skończoność i miara przestaje jednak adekwatnie opisywać przypadek Bytu, którego drogi i zamysły są niezmierzone, to znaczy który działa w świecie w sposób ciagle nowy i zadziwiający, który nie ma nad sobą żadnego prawa wyznaczającego gra- 


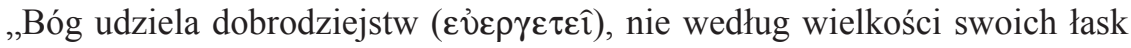

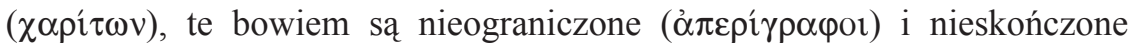

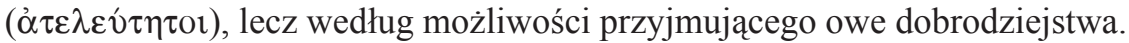
W takim bowiem stopniu, w jakim Bóg jest w stanie czynić dobro, stworzenie nie jest w stanie tego dobra przyjąć. W rzeczywistości poza wszel-

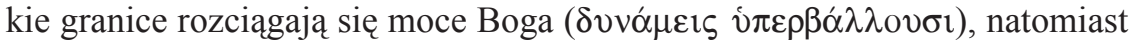
stworzenia są zbyt słabe, aby przyjąć ich wielkość ( $\mu \varepsilon \varepsilon \gamma \varepsilon \theta o \varsigma)$ i musiałyby odmówić przyjęcia, gdyby Bóg w odpowiedni sposób nie odmierzał i nie ograniczał według pojemności każdego sumy swych darów, jakie mają mu przypaść w udziale"15.

Przystępując do analizy tego tekstu, warto na wstępie przyjrzeć się znacze-

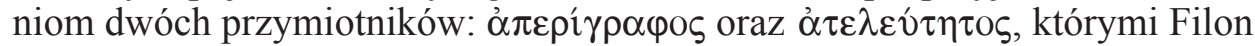

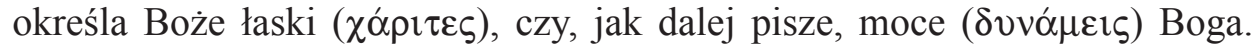
Pierwszy pochodzi od czasownika $\pi \varepsilon \rho \imath \gamma \rho \alpha ́ \varphi \omega=$,określić”, ,zdefiniować”, „ograniczyć"16, drugi od $\tau \varepsilon \lambda \varepsilon v \tau \alpha ́ \alpha \omega=$,,skończyć”, ,zrealizować”17. W połączeniu z $\alpha$-privativum słowa te mogą opisywać coś nieokreślonego, niedokończonego, a więc i niedoskonałego, albo też coś nieskończonego i niczym nieograniczonego. Kontekst wypowiedzi, który mówi o kruchości stworzenia, a w związku z tym o niemożliwości przyjęcia przez nie ogromu Bożych darów i mocy, prowadzi nas jednak do wniosku, iż obu przymiotnikom nie można nadawać znaczenia związanego z niedoskonałością czy niedokończonością. To raczej skończone stworzenie okazuje się być czymś niedoskonałym przy zestawieniu z nieskończonym nadmiarem Bożych darów. Jest to o tyle istotne, gdyż właśnie w tym miejscu Filon nadaje nowe, pozytywne znaczenie kategorii nieskończoności. Boskie moce, choć doskonałe, gdyż wypływają z Bożej dobroci udzielającej się stworzeniu, w Bogu nie mają żadnej miary, ani ograniczenia. Poza Bogiem jednak, a więc działając w świecie, zostają one w jakiś sposób „odmierzone” według miary przyjmujących je stworzeń. U swego źródła, a więc w Bogu, pozostają jednak nieograniczone (ỏ $\pi \varepsilon \rho i ́ \gamma \rho \alpha \varphi o \imath)$

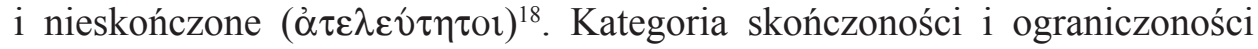
będzie od tej pory wiązana z niedoskonałością stworzenia w odróżnieniu od

nice Jego aktywności, lecz który sam udziela swych dobrodziejstw jak chce i komu chce. W przypadku takiego Bytu, doskonałość polega nie na dojściu do jakiegoś kresu czy spełnienia, lecz na nieustannym udzielaniu się, które nie ma granic ani żadnej miary.

${ }^{15}$ Philo Alexandrinus, De opificio mundi 23, ed. L. Cohn - P. Wendland - S. Peiter: Philonis Alexandrini opera quae supersunt, Berlin 1896-1926, vol. 1, 7, thum. L. Joachimowicz: Filon Aleksandryjski, Pisma, t. 1, Warszawa 1986, 38 (thum. poprawione).

${ }^{16}$ Por. Liddell - Scott, s. 1370-1371.

${ }^{17}$ Por. tamże, s. 1771.

${ }^{18}$ Por. Philo Alexandrinus, Quod Deus sit immutabilis 77-81, gdzie Filon rozróżnia moce „czyste”, które istnieją tylko w Bogu i pozostają zupełnie niepoznawalne, oraz moce ,złagodzone”, do których ma dostęp człowiek, poprzez fakt, iż zostały w jakimś stopniu „odmierzone”, czy dostosowane do możliwości przyjmującego je i poznającego stworzenia. 
pozytywnie pojmowanej nieskończoności Boskiego Dobra, którego twórczej i rządzącej wszystkim mocy nic nie jest w stanie ograniczyć.

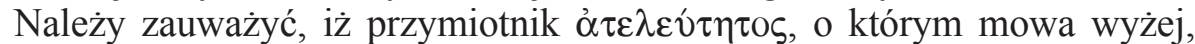
pojawia się również w jednej z definicji nieskończoności Arystotelesa ${ }^{19}$. Jest to niezmiernie ważne, gdyż w tym, jak i w wielu innych miejscach Aleksandryjczyk świadomie polemizuje z tezami filozofów greckich jeśli chodzi o pojęcie nieskończoności. Według Stagiryty, nie istnieją aktualnie byty nieskończone, to znaczy takie, których proces przemierzania ${ }^{20}$ czy to fizycznego, czy intelektualnego byłby nieskończony ${ }^{21}$. O skończoności każdej substancji decyduje bowiem ograniczająca ją forma ${ }^{22}$. Dla Filona natomiast takim właśnie nieprzemierzonym i przez nic nieograniczonym bytem są Boskie moce i sam Bóg. I nie chodzi tu jedynie o przemierzalnośćc ${ }^{23}$ czy ograniczenie w sensie fizycznym,

${ }^{19}$ Por. Aristoteles, Physica III 204a 5, ed. I. Bekker: Aristotelis opera edidit Academia Regia Borussica, vol. 1, Berlin 1831, 204.

${ }^{20}$ Arystoteles (Metaphysica XI 1066a 35 - 1066b 1; Physica III 204a 2-7), konstruując liczne definicje nieskończoności, posługuje się przymiotnikami, imiesłowami i rzeczownikami pochodzą-

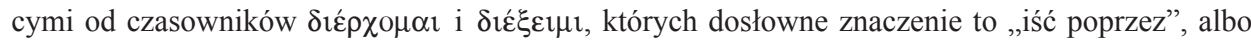
„prze-chodzić”. Ogólna definicja nieskończoności Stagiryty jest następująca: „Nieskończone jest

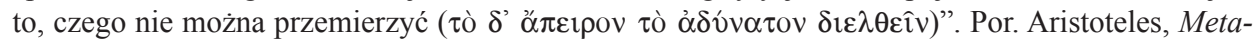
physica XI 1066a 35, ed. Bekker, vol. 2, s. 1066. Polscy thumacze dzieł Stagiryty używają jednakże różnych terminów opisujących owe „przemierzanie”. K. Leśniak posługuje się czasownikami „przebiegać” (Arystoteles, Metafizyka, Warszawa 2009, 204) oraz „prześledzić” (Arystoteles, Zachęta do filozofii. Fizyka, Warszawa 2010, 124). A. Krąpiec i A. Maryniarczyk (Arystoteles, Metafizyka, t. 2, Lublin 1996, 176) wybrali natomiast słowa „przekraczać” i „przemierzać”. W niniejszym tekście, nawiązując do Arystotelesowskiej definicji nieskończoności, będziemy zawsze posługiwali się czasownikiem ,przemierzać”. Problem z tłumaczeniem pojawi się jednak wówczas, gdy Stagiryta, jak i Ojcowie Kościoła, mówiąc o niemożliwości przemierzenia nieskończonego, będą posługiwali

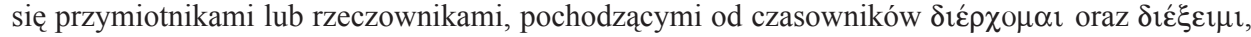
których odpowiedniki nie istnieją w języku polskim. Wówczas będziemy musieli utworzyć pewnego typu neologizmy takie jak „nieprzemierzalny” czy „nieprzemierzalność”. Wydaje się jednak, że brzmią one lepiej niż ich odpowiedniki, utworzone od czasowników „prześledzić” czy „przebiegać". Poniżej wrócimy jeszcze do tej kwestii.

${ }^{21}$ Por. Aristoteles, Physica III 204b 5-21. Jedynym sposobem istnienia nieskończoności jaki przyjmuje Arystoteles to nieskończoność potencjalna (por. tamże III 206a 14-18). Oznacza to, iż nieskończoność może odnosić się według niego do jakiegoś ciągu następujących po sobie zjawisk lub też procesu powstawania i ginięcia. Proces ten na każdym etapie jest skończony, jednakże rozwijając się jest zawsze różny i w tym sensie zmierza potencjalnie do nieskończoności (por. tamże III 206a 21-33). Nieskończonymi w takim razie są również czas i ruch, które nie są substancją aktualnie istniejąca, lecz funkcją dotyczącą zmian zachodzących w świecie (por. tamże III 207b 21-25). Stagiryta przyjmuje więc funkcjonalną, a nie substancjalną koncepcję nieskończoności. Nie istnieje według niego byt w akcie, który byłby nieskończony. Zmiany, którym ów aktualny byt ulega, mogą jednak być nieskończone. Por. R. Radice, Una proposta di lettura della „Fisica” di Aristotele, w: Aristotele, Fisica. Testo greco a fronte, Milano 2011, 33.

${ }^{22}$ Por. Aristoteles, Physica III 207a 33 - b 1.

${ }^{23}$ Jestem świadom, o czym już wyżej wspomniałem, że tworzę w tym miejscu pewien neologizm. Czynię to jednak dlatego, że podobny neologizm utworzy Klemens Aleksandryjski. Nawiązując bowiem do definicji Arystotelesa powie, że Bóg jest nieskończony, lecz nie w sensie „nie- 
gdyż Bóg jest absolutnie niecielesny, lecz także o przemierzalność intelektualną czy intelektualne objęcie istoty Boga. Choć, podobnie jak Arystoteles, Filon twierdzi, iż wszystkie byty aktualnie istniejące mają jakieś określone formy

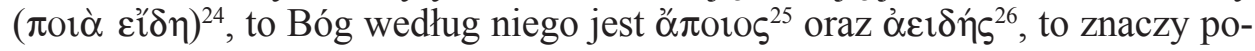
zbawiony jakiegokolwiek określenia i formy. Tym właśnie różni się Bóg Aleksandryjczyka od arystotelesowskiego Pierwszego Nieruchomego Poruszyciela, który jest czystą formą. Polemizując natomiast z Platonem, Filon powie, iż Bóg

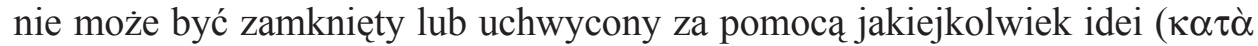

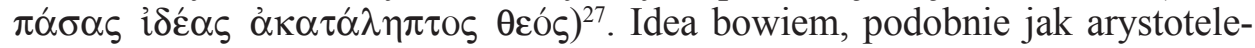
sowska forma, jest czymś, co nadaje miarę, ale i co posiada miarę, a więc pewne ograniczenie. Dlatego też, uważa Aleksandryjczyk, zadaniem filozofa nie jest ujmowanie Absolutu w kategoriach fizycznych czy metafizycznych, lecz kontemplowanie Jego czystego istnienia, pozbawionego jakiejkolwiek formy $(\mu о \rho \varphi \eta)^{28}$. „W rzeczywistości bowiem - dodaje - i tak możemy uchwycić je-

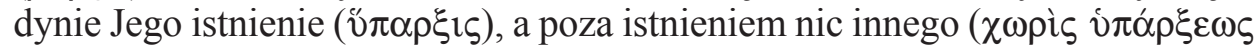
oט̉oćv)"29. Skończony intelekt ludzki nie jest więc w stanie objąć czegoś nieskończonego, czegoś, co nie może być objęte nawet poprzez formę natury inteligibilnej, która zawsze jest jakimś określeniem, a więc i ograniczeniem.

A propos polemiki z Arystotelesem, należy również zwrócić uwagę na dwa kolejne słowa, które pojawiają się w cytowanym wyżej tekście ${ }^{30}$ : $\hat{v} \pi \varepsilon \rho \beta \alpha ́ \alpha \lambda \lambda \omega$ oraz $\mu \dot{\varepsilon} \gamma \varepsilon \theta o \varsigma$. Stagiryta bowiem stwierdza, że „,nie istnieje nieskończoność przez dodawanie $\mathrm{w}$ sensie przekraczania wszelkiej wielkości

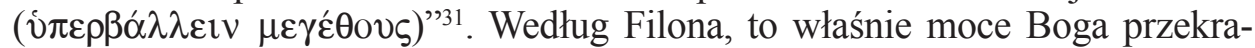
czają ( o wielkość w sensie fizycznym, o której myślał Arystoteles, lecz o jakąś niezmierzoną inteligibilną siłę, której Stagiryta nie był sobie w stanie wyobrazić,

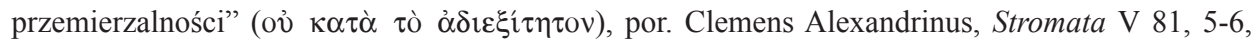
ed. O. Stählin, GCS 15, Leipzig 1906, 380. Fragment ten zacytujemy w całości i skomentujemy w dalszej części niniejszego tekstu. Już teraz jednak chcemy zaznaczyć, iż nowa definicja nieskończoności, którą skonstruuje Klemens ma swoje podstawy w rozważaniach Filona i jest polemiką z tezami Stagiryty, który pojmuje nieskończoność jako coś nieprzemierzalnego ( $\dot{\omega} \varsigma \dot{\alpha} \delta \varepsilon \varepsilon \xi i ́ \tau \eta \tau o v)$. Zob. Aristoteles, Physica III 204a 14, ed. Bekker, t. 1, s. 204.

${ }^{24}$ Por. Philo Alexandrinus, Quod Deus sit immutabilis 62, ed. Cohn - Wendland - Peiter, vol. 2, s. 70.

${ }^{25}$ Por. tenże, Legum allegoriae I 36, ed. Cohn - Wendland - Peiter, vol. 1, s. 70; tamże I 51, ed. Cohn - Wendland - Peiter, vol. 1, s. 73; tamże III 36, ed. Cohn - Wendland - Peiter, vol. 1, s. 121.

${ }^{26}$ Por. tenże, De posteritate Caini 15, ed. Cohn - Wendland - Peiter, vol. 2, s. 4; tenże, Quod deterius 86-87, ed. Cohn - Wendland - Peiter, vol. 1, s. 277-278.

${ }^{27}$ Por. Philo Alexandrinus, De somniis I 67, ed. Cohn - Wendland - Peiter, vol. 1, s. 219.

${ }^{28}$ Por. tenże, Quod Deus sit immutabilis 55, ed. Cohn - Wendland - Peiter, vol. 2, s. 68-69; tenże, De confusione linguarum 134-138, ed. Cohn - Wendland - Peiter, vol. 2, s. 254-255.

${ }^{29}$ Por. Philo Alexandrinus, Quod Deus sit immutabilis 62, ed. Cohn - Wendland - Peiter, vol. 2, s. 70 .

${ }^{30}$ Chodzi o fragment z De opificio mundi 23.

${ }^{31}$ Aristoteles, Physica III 207a 33 - b 1, ed. Bekker, vol. 1, s. 207, thum. Leśniak, s. 135. 
bądź bez której istnienia jego system, całkiem dobrze funkcjonował. Tak więc dopiero biblijna koncepcja stworzenia połączona z konceptem Bożej opatrzności, do której odwołuje się Filon, wymaga wprowadzenia nieskończonej Boskiej mocy, która stwarza, podtrzymuje świat w istnieniu i nim opatrznościowo rządzi. Nie potrzebował takiej mocy arystotelesowski Nieruchomy Poruszyciel, który zamknięty w swoim szczęściu był jedynie przyczyną ruchu w świecie, ani też platoński Demiurg, który stwarzając świat, a właściwie porządkując chaotyczną materię, wpatrywał się w świat doskonale skończonych i określonych idei ${ }^{32}$.

O nadmiarze Boskiej dobroci, której skończone stworzenie nie jest w stanie przyjąć, pisze Filon jeszcze w wielu innych miejscach swoich pism. Porównuje on na przykład Boskie moce do deszczu lub płynącej wody, która nie tylko napełnia stworzenia tym, co są w stanie przyjąć, lecz wręcz się z nich przelewa. W ten metaforyczny sposób Aleksandryjczyk stara się wskazać, iż Bóg jest niewyczerpanym źródłem dobra, albo też, że Bóg to Dobro, do którego istoty należy niemające kresu udzielanie sięe 33 . Jego ulubioną metaforą opisującą nieskończoność Boga i nieskończoność Jego mocy wydaje się być jednak metafora słońca i światła. Słońce jest oczywiście symbolem Boga - Jego natury i sposobu działania w świecie. Choć znajduje się ono ponad ziemią - tak jak Bóg jest transcendentny względem stworzenia - to jednak ma wpływ na to, co dzieje się w świecie za sprawą ogarniającego wszystko światła, które od niego pochodzi. Tym światłem, a właściwie niezliczonymi promieniami są Boskie

${ }^{32}$ I właśnie z tego powodu Filon nie nazywa Boga dobrym, bądź Dobrem samym, jak to czynił Platon (Timaeus 29a-30a; Respublica 517c), lecz uważa, iż jest On „lepszy od samego Dobra

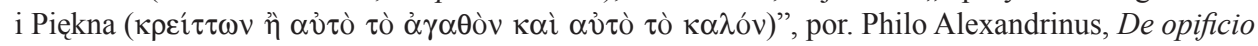
mundi 8, ed. Cohn - Wendland - Peiter, vol. 1, s. 3. Owa wyższość Boga względem Dobra polega na nadmiarze dobroczynnej mocy, która zeń wypływa. Platońskie Dobro było jedynie skończoną miarą wszelkich dobrych bytów, które miały pojawić się w świecie widzialnym. Dlatego też w innym miejscu (tenże, Legatio ad Gaium 5, ed. Cohn - Wendland - Peiter, vol. 5, s. 156, tłum własne) Aleksandryjczyk stwierdzi, iż Bóg jest ,piękniejszy od Piękna, szczęśliwszy od szczęścia, bardziej obfitujący niż sama obfitość, i jeśli cokolwiek innego istnieje, w taki sposób jak jedna z wymienionych tutaj rzeczy, On jest od tego doskonalszy (

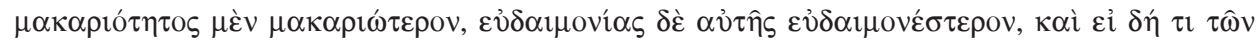

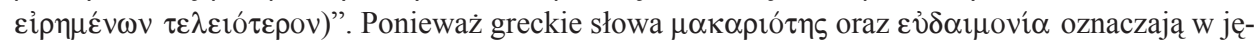
zyku polskim po prostu „szczęście”, w różnych odcieniach znaczeniowych, postanowiłem oddać pierwszy wyraz jako „szczęście”, drugi zaś jako „obfitość”. W rzeczywistości bowiem Filon w tym, jak i w wielu innych miejscach, pragnie wskazać na nadmiar piękna, dobra i szczęścia, które nie da się zamknąć w żadnej z kategorii, o których mówili filozofowie greccy. Por. Philo Alexandrinus, De vita contemplativa 2; tenże, De praemiis et poenis 40.

${ }^{33}$ Por. Philo Alexandrinus, De fuga et inventione 95-96; tenże, De migratione Abrahami 155156; tenże, De mutatione nominorum 129; tenże, De virtutibus 77-79; tenże, Legum allegoriae I 34; III 40; III 106; III 166; tenże, De agricultura 173; tenże, De plantatione 87-92. Zob. G. Reale - R. Radice, La genesi e la natura della filosofia mosaica. Struttura, metodo e fondamenti del pensiero filosofico e teologico di Filone di Alessandria, w: Filone di Alessandria, Tutti i trattati del commento allegorico alla Bibbia. Testo greco a fronte, ed. R. Radice, Milano 2005, LXXXV-LXXXVI. 
moce $^{34}$. Aby uniknąć wszelkich materialnych skojarzeń, które taka metafora mogłaby implikować, Aleksandryjczyk podkreśla, iż w przypadku Boga chodzi o światło inteligibilne, nieuchwytne za pomocą zmysłów:

„Oko Bytu [tj. Boga] bowiem, nie potrzebuje innego światła, aby widzieć, ale On sam będąc światłem archetypicznym wyrzuca z siebie niezliczone promienie ( $\mu$ vpí $\alpha \varsigma$ $\alpha \kappa \tau \hat{\imath} v \alpha \varsigma$ ), z których żaden nie jest dostrzegalny poprzez

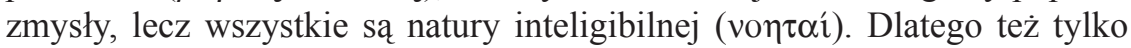

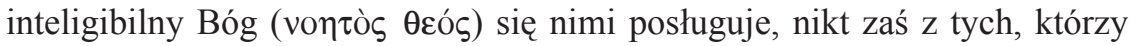
są cześscią stworzenia. To, co stworzone bowiem jest zmysłowe, podczas gdy natura inteligibilna jest nieuchwytna za pomocą zmysłów"35.

Filon, choć odwołuje się do znanej platońskiej parabolii", wyraźnie ją reinterpretuje. Metafora słońca bowiem była potrzebna Platonowi tylko dla ukazania transcendencji idei Dobra. Tak jak słońce, pozostając wysoko ponad ziemia, jest przyczyną rodzenia się i wzrostu bytów cielesnych oraz przyczyną postrzegania rzeczy widzialnych, tak idea Dobra, choć transcendentna względem bytu, jest przyczyną istnienia tego, co istnieje i poznawalności tego, co poznawalne. Według myśliciela żydowskiego natomiast, metafora słońca dotyczy również Bożej wszechmocy. Oto bowiem Bóg, niczym słońce, wyrzuca

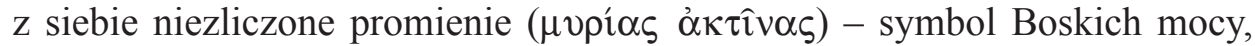
o których Platon nic nie wspomina. Owe promienie są oczywiście natury inte-

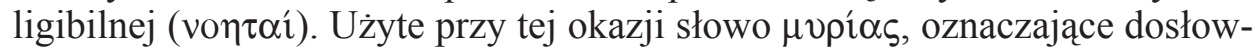
nie „dziesięć tysięcy”, było używane w języku greckim również na określenie niezliczonej, czy nieskończonej ilości jakichś rzeczy ${ }^{37}$. Bóg jest więc według

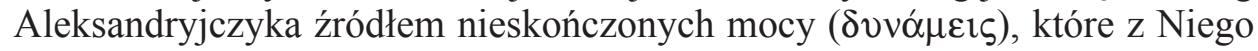
wypływają i które wpływają na to, co dzieje się w świecie widzialnym ${ }^{38}$.

Ponadto Filon posługując się metaforą słońca, dochodzi do kolejnego wniosku, na temat którego Platon milczy, albo też mówi rzecz zgoła przeciwną ${ }^{39}$. Otóż samo słońce, zdaniem Aleksandryjczyka, jest oślepiające. Człowiek może jedynie przez krótki czas na nie patrzyć. Nie może się do niego zbliżyć,

${ }^{34}$ Por. Philo Alexandrinus, Quod Deus sit immutabilis 77-80; tenże, De somniis I 72-75, gdzie zostaje wyjaśniona metafora słońca.

${ }^{35}$ Tenże, De cherubim 97, ed. Cohn - Wendland - Peiter, vol. 1, s. 193-194, thum. własne.

${ }^{36}$ Por. Plato, Respublica 507d-509d. Szerzej na temat ontologicznych i epistemologicznych implikacji platońskiej metafory słońca zob. D. Mrugalski, Metamorfozy platońskiej „metafory stońca" (Resp. 509 b) w hetero- i ortodoksyjnej teologii (I-III w.): Gnostycyzm, Klemens z Aleksandrii i Orygenes, VoxP 37 (2017) t. 68 [tekst w druku].

${ }^{37}$ Por. Lampe, s. 889.

${ }^{38}$ Por. Philo Alexandrinus, De confusione linguarum 171-172, ed. Cohn - Wendland - Peiter ,

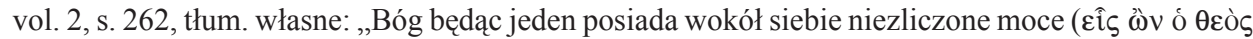

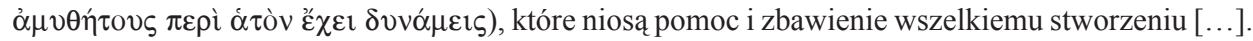

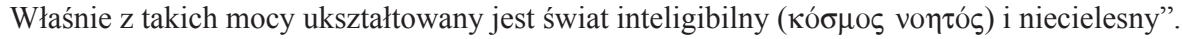

${ }^{39}$ Według Platona idea Dobra zostaje określona jako poznawalna ( $\gamma(\gamma \nu \omega \sigma \kappa o \mu \varepsilon ́ v \eta)$. Por. Plato, Respublica 508e, ed. J. Adam: The Republic of Plato, vol. 2, Cambridge 1902, 61. 
zbadać czy nawet ogarnąć wzrokiem. Może natomiast wnioskować na temat jego jasności czy ciepła na podstawie promieni, które od niego pochodzą. Podobnie jest z Bogiem - sugeruje Filon. Ponieważ poprzez swoje moce udziela się On światu, człowiek jest w stanie dojść do stwierdzenia faktu Jego istnienia. Jest też w stanie, do pewnego stopnia, mówić o Jego mocy - a więc o Jego sposobie rządzenia światem, o Jego dobroci, sprawiedliwości, mądrości etc. Bożej istoty jednak nigdy nie jest w stanie do końca pojąć, gdyż jest ona „oślepiająca", a więc niepoznawalna ${ }^{40}$.

Poprzez koncept Boskich mocy Filon rozwiązuje również bardzo ważny problem filozoficzny dotyczący relacji między Bożą transcendencją i immanencją. Dzięki mocom bowiem, Bóg staje się wszechobecny, wszechwładny i wszechwiedzący. $Z$ drugiej zaś strony, można powiedzieć, iż Bóg, ze względu na swą transcendencję, a zwłaszcza ze względu na nieskończoność swojej natury, nie może być zamknięty w żadnym miejscu i w żadnym elemencie materialnego świata. Nic nie jest w stanie Go objaćc, czy ogarnąć. Dlatego też Aleksandryjczyk stwierdza, że Bóg jest ogarniającym wszystko, lecz sam pozostaje nieogarniony:

„Przez Boga zostało wypełnione wszystko (í $\pi$ ò $\delta \dot{\varepsilon} ~ \tau o \hat{v} \theta \varepsilon \circ \hat{v} \pi \varepsilon \pi \lambda \eta \dot{\eta} \rho \omega \tau \alpha \mathrm{l}$ $\tau \grave{\alpha} \pi \alpha ́ v \tau \alpha)$. Będąc bowiem ogarniającym wszystko, lecz nie ogarnionym

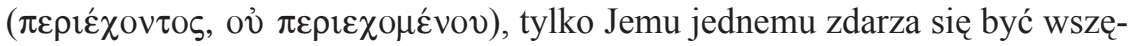

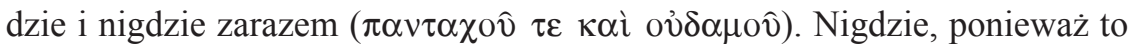
On, wraz z ciałami, stworzył i przestrzeń i miejsce. Należy więc twierdzić, że

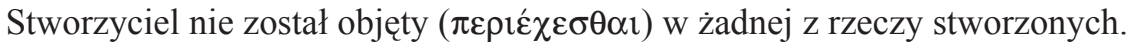
Jest jednak wszędzie, ponieważ rozciągnąwszy swoje moce poprzez ziemię, wodę, powietrze i niebo, żadnej części świata nie pozostawił opuszczonej”41.

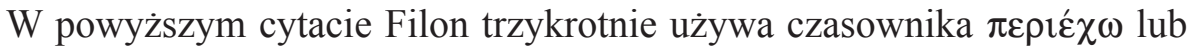
imiesłowów od niego pochodzących. Czasownik ten wyraża ideę otaczania

${ }^{40}$ Por. Philo Alexandrinus, Quod Deus sit immutabilis 78; tenże, De somniis I 72. Ponieważ

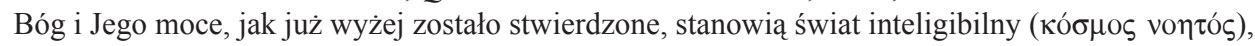

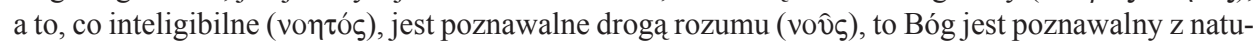
ry. Owa poznawalność jest jednak - według Filona - ograniczona. Ludzki intelekt może w pewnym sensie penetrować to, co inteligibilne, ale ze względu na nieskończoność świata inteligibilnego nie jest w stanie ogarnąć go w całości. Dlatego też Aleksandryjczyk będzie niekiedy polemizował z Pla-

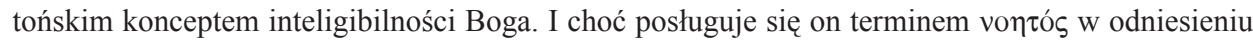

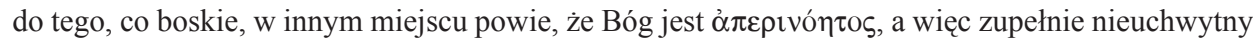
przez jakiekolwiek intelektualne dociekanie, ponieważ transcenduje wszystko to, co jest poznawalne drogą umysłu. Por. Philo Alexandrinus, De mutatione nominum 15; tenże, De fuga et inventione 141. Szerzej na temat Boga jako oślepiającego światła zob. F. Calabi, God's Acting, Man's Acting. Tradition and Philosophy in Philo of Alexandria, Leiden 2008, 57-69 (The Dazzling Light: A Metaphor on the Unknowability of God). Zob. także tenże, Conoscibilità e inconoscibilità di Dio in Filone di Alessandria, w: Arrhetos Theos. L'ineffabilità del primo principio nel medio platonismo, ed. F. Calabi, Pisa 2002, 35-54.

${ }^{41}$ Philo Alexandrinus, De confusione linguarum 136, ed. Cohn - Wendland - Peiter, vol. 2, s. 254, thum. własne. 
kołem lub zamykania, a dokładniej: „posiadania czegoś poprzez objęcie”

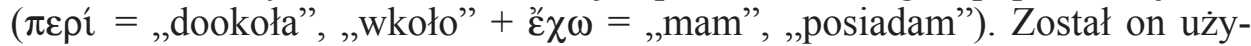
ty również w III księdze Fizyki Arystotelesa, gdzie filozof snuje swoje rozważania na temat sposobu istnienia nieskończoności ${ }^{42}$. Według Stagiryty, zgodnie $\mathrm{z}$ jego hylemorficzną teorią bytu, nie może istnieć aktualnie jakaś nieskończona wielkość. Każda bowiem substancja, jak już to wyżej powiedzieliśmy, jest w jakiś sposób „zamknięta”, to znaczy ograniczona przez formę, która jest jej kresem ( $\pi \dot{\varepsilon} \rho \alpha \varsigma)$. Forma jest czymś, co obejmuje ( $\pi \varepsilon \rho \imath \varepsilon \varepsilon \chi \varepsilon \imath)$ materię. Jeśli więc istnieje jakaś nieskończoność, to tylko potencjalnie - poprzez dzielenie materii na coraz mniejsze cząstki. Podobnie więc jak materia, owa potencjalna nieskończoność jest objęta $(\pi \varepsilon \rho \imath \varepsilon ́ \chi \varepsilon \tau \alpha \iota)$ przez jakąś formę ${ }^{43}$. Według Aleksandryjczyka natomiast, Bóg jest nieskończony i dlatego jest nieobejmowalny (ov̉ $\pi \varepsilon \rho \imath \varepsilon \chi o ́ \mu \varepsilon v o \varsigma$ ), i to zarówno intelektualnie jak

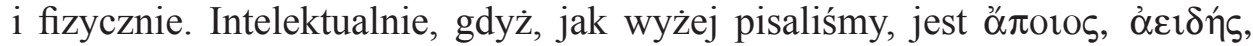

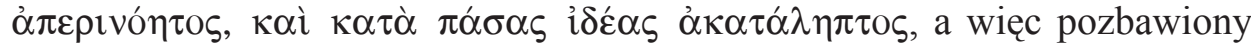
jakiejkolwiek jakości i formy oraz nieredukowalny do żadnej idei czy konceptu myślowego. Jest nieobejmowalny fizycznie, gdyż żadne stworzenie, ani miejsce, ani nawet świat cały, nie jest w stanie pomieścić, czy przyjąć, już nie tylko Boga, ale chociażby jednej z Jego nieskończonych mocy. Wyrażenie $\pi \varepsilon \rho t \varepsilon ́ \chi \omega \nu$, o $\pi \varepsilon \rho t \varepsilon \chi o ́ \mu \varepsilon v o \varsigma$ („ogarniający, lecz nieogarniony”) wskazuje więc na nieskończoność Boga pod względem natury i mocy, i wydaje się być kolejnym punktem polemicznym z tezami Arystotelesa na temat nieskończoności. Należy również zauważyć, iż pojawia się ono nie tylko w wyżej cytowanym tekście, ale jeszcze w wielu innych miejscach pism Filona, gdzie zostaje użyte zarówno w sensie ontologicznym, jak i epistemologicznym ${ }^{44}$. Tak więc istoty Boga żadne miejsce nie jest w stanie objać, On zaś poprzez swoje moce obejmuje wszystko i wszystkim opatrznościowo włada. Jest więc

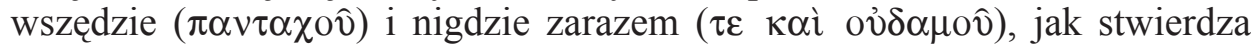
wyżej przytoczony tekst Filona. Z punktu widzenia epistemologicznego natomiast, ludzki intelekt nie jest w stanie objąć nieskończonej natury Boga. On zaś wszystko wie, to znaczy swoim intelektem obejmuje wszystko, co istnieje i co wydarza się w świecie. Formuła $\pi \varepsilon \rho \imath \varepsilon ́ \chi \omega v$, ov̉ $\pi \varepsilon \rho \imath \varepsilon \chi o ́ \mu \varepsilon v o \varsigma$ skupia więc niczym w soczewce całą teologię Filona: wyjaśnia, w jaki sposób możliwe jest pogodzenie Bożej transcendencji, a więc nieskończoności, niecielesności, ponadczasowości i niepoznawalność Boga, z Jego immanencją, czyli wszechmocą, wszechobecnością, wszechwiedzą i opatrznością. Mając tak wiele wypowiedzi dotyczących nieskończoności Boga w dziełach Filona, można zadać pytanie, dlaczego tak niewielu uczonych dostrzega

${ }^{42}$ Por. Aristoteles, Physica III 207a 35 - b 1, ed. Bekker, vol. 1, s. 207.

${ }^{43}$ Por. tamże.

${ }^{44}$ Por. Philo Alexandrinus, Legum allegoriae I 44; III 4-6; III 51; tenże, De somniis I 63-67; I 184-186; tenże, De posteritate Caini 14-15; tenże, De sobrietate 63; tenże, De migratione Abrahami 182-183. 
oryginalność tego konceptu w jego myśli i nadal twierdzi, że dopiero Plotyn jako pierwszy zaczął mówić o nieskończoności Boga w sposób pozytywny. Jest tak być może dlatego, iż Filon ani razu w odniesieniu do Boga nie posługuje

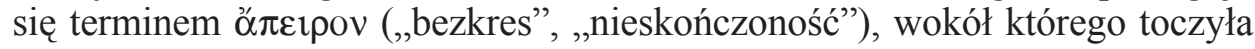
się dyskusja wśród filozofów starożytnych. Czyni to natomiast, jak to zwykli czynić platonicy, w odniesieniu do preegzystującej materii. To Boskie moce nadają miarę, a więc i kres, bytom, które wcześniej były „,bezkresne, nieokreślone

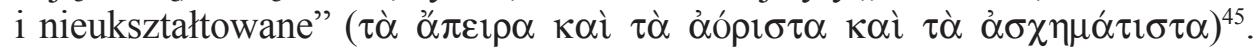
$\mathrm{Z}$ tego zestawienia przymiotników wynika, iż termin ő dług Filona zbyt negatywne konotacje, skoro służył do opisu bezkresnej i nieokreślonej materii, by w równej mierze posługiwać się nim w opisie natury Boga. Bóg nie jest - według niego - totalną nieokreślonością, lecz Dobrem, którego udzielanie się nie ma kresu. Posiadamy jednakże tekst Aleksandryj-

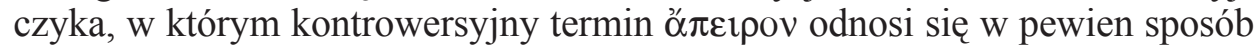
również do tego, co boskie. Oto bowiem, gdy Filon opisuje drogę upodobnienia się człowieka do Boga, stwierdza, iż mędrzec w pewnym momencie zatrzymuje się i odkrywa, iż „przedmiot”, który pragnie poznać, nieustannie

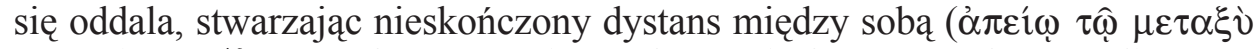

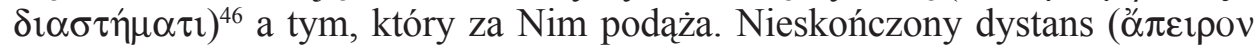
$\delta ı \alpha ́ \sigma \tau \eta \mu \alpha$ ), o którym mówi myśliciel żydowski, nie może być interpretowany w sensie fizyczno-przestrzennym. Jest oczywiste, iż Bóg - według Filona - jest zupełnie niecielesny i nie posiada żadnego miejsca, które miałoby się oddalać w nieskończoność. Tekst ten opowiada językiem metaforycznym o niekończącej się drodze intelektualnej i etycznej, którą przebywa ten, kto pragnie poznać Boga i upodobnić się do Niego. Jest ona nieskończona, ponieważ jej cel, czyli sam Bóg jest nieskończony. Upodabnianie się do Nieskończonego siłą rzeczy musi trwać w nieskończoność i nigdy nie może osiągnąć kresu ${ }^{47}$.

Podobne koncepty, a nawet powtórzenia tych samych interpretacji tekstów biblijnych $^{48}$, znajdujemy u kolejnego, tym razem już chrześcijańskiego, myśliciela z Aleksandrii - Klemensa. Jeśli chodzi o jego doktrynę Boga, nie będziemy powtarzali tego, o czym pisaliśmy w innym miejscu. W artykule na temat przeobrażeń platońskiej metafory słońca ${ }^{49}$ pokazaliśmy, że Klemens, podobnie jak to widzieliśmy u Filona, porównuje Boga do niewyczerpanego źródła

${ }^{45}$ Tenże, De specialibus legibus I 48, ed. Cohn - Wendland - Peiter, vol. 5, s. 12.

${ }^{46}$ Por. tenże, De posteritate Caini 18-19, ed. Cohn - Wendland - Peiter, vol. 2, s. 4.

${ }^{47}$ Por. tenże, De specialibus legibus I 41-50.

${ }^{48}$ Por. Clemens Alexandrinus, Stromata II 5, 4 - 6, 3; V 71, 4-5, gdzie Klemens, podobnie jak Filon, dokonuje alegorycznej interpretacji wydarzenia spotkania Mojżesza z Bogiem (Por. Wj 33, 13-23) i dochodzi do podobnych konkluzji. Stwierdza on bowiem, iż Bóg, mimo usilnej prośby

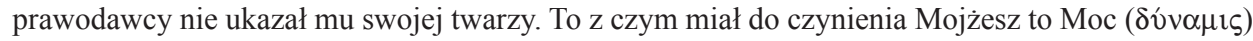

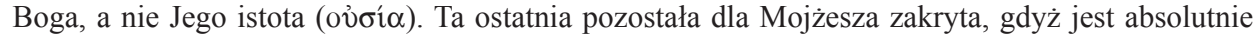
nieogarniona i niemożliwa do uchwycenia przez ludzki intelekt. Zob. Philo Alexandrinus, De specialibus legibus I 41-50; tenże, De posteritate Caini 13-16; tenże, De mutatione nominorum 8-12.

${ }^{49}$ Por. przypis nr 36. 
światła, które choć transcendentne ma wpływ na to, co dzieje się w świecie

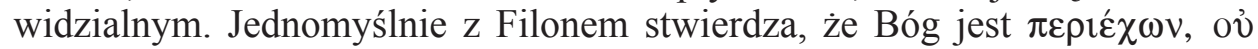
$\pi \varepsilon \rho \imath \varepsilon \chi \mu_{\mu \varepsilon v o \varsigma}$ (,ogarniającym, lecz nieogarnionym”) ${ }^{50}$ i w analogiczny sposób reinterpretuje słynną metaforę Platona ${ }^{51}$. Chcielibyśmy jednak skupić się w tym miejscu na kilku ważnych fragmentach, w których Klemens, nie tylko za pomocą metafor, lecz także explicite polemizuje z poglądami filozofów greckich na temat pojęcia nieskończoności. I tak, w swych Kobiercach, gdy porusza temat niepoznawalności i niewyrażalności Boga stwierdza:

„Jakże bowiem może być wyrażalne to, co ani nie jest gatunkiem, ani rodzajem, ani formą (દî̉os), ani atomem, ani liczbą, ani akcydensem, ani tym, czemu przysługuje jakiś akcydens. Ani też nikt nie mógłby słusznie nazwać Go

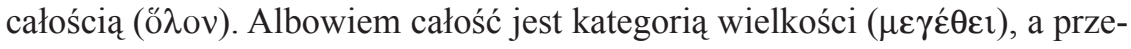
cież Bóg jest ojcem całego [świata]. Nie można też mówić o jakichś częściach

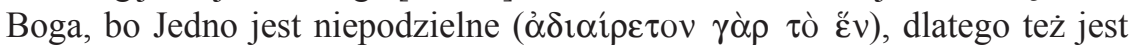

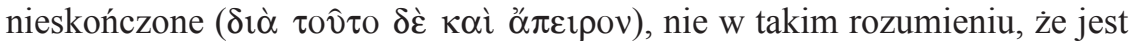

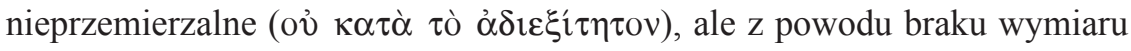

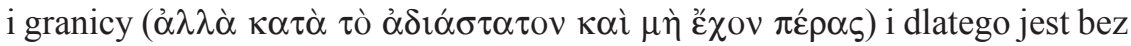

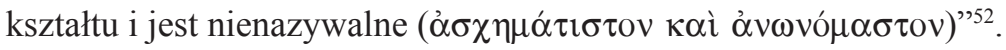

Tekst ten jest niezwykle istotny, gdyż po raz pierwszy w historii filozofii, transcendentny i doskonały Absolut zostaje określony terminem ö $\pi \varepsilon ı$ ipov, który do tej pory posiadał konotacje negatywne, to znaczy opisywał rzeczywistość niedoskonałą lub niedokończoną ${ }^{53}$. Jednakże nie tylko w warstwie terminologicznej tkwi oryginalność powyższych stwierdzeń. Wyliczając bowiem różnego rodzaju kategorie, o których pisał Arystoteles, takie jak: gatunek, rodzaj czy akcydens, Klemens stwierdza, iż Bóg nie należy do żadnej

${ }^{50}$ Clemens Alexandrinus, Stromata II 6, 2-3, GCS 15, 116. Por. tamże VII 5, 5, ed. O. Stählin, GCS 17, Leipzig 1909, 6.

${ }^{51}$ Ze względu na to, iż Bóg jest niewyczerpanym źródłem udzielającego się dobra i mocy (por. tamże I 85, 5 - 86, 3; II 5, 4-5; VI 47, 4), także Klemens, podobnie jak Filon, będzie stawiał Boga „wyżej” niż Platon swoją ideę Dobra. Stwierdzi on nie tylko, iż Bóg jest ponad wszelką przyczyna, ponad Jednem, Monadą i ponad wszelkim bytem inteligibilnym, o którym mówił Platon, ale także, że nazwy takie, jak Dobro, Bóg, Stwórca czy Ojciec, są nazwami niewłaściwymi w odniesieniu do tego, czym jest Bóg. Por. tenże, Paedagogus I 71, 1; tenże, Stromata VII 2, 2-3; V 38, 6; V 65, 2; V 82, 1-2; VI 165, 5 - 166, 3.

${ }^{52}$ Clemens Alexandrinus, Stromata V 81, 5-6, GCS 15, 380, tłum. własne. Choć pierwsza część powyższego tekstu odpowiada tłumaczeniu J. Niemirskiej-Pliszczyńskiej (Klemens Aleksandryjski, Kobierce zapisków filozoficznych dotyczacych prawdziwej wiedzy, t. 2, Warszawa 1994, 66), to jednak w drugiej jego części musiałem dokonać istotnych zmian, gdyż tłumaczka prawdopodobnie nie zorientowała się, iż Klemens posługuje się w tym miejscu terminami technicznymi pojawiającymi się w Fizyce Arystotelesa oraz w Parmenidesie Platona, a w związku z tym użyła niewłaściwych polskich odpowiedników słów greckich zaciemniając znaczenie tekstu.

${ }^{53}$ Również Filon, jak pokazaliśmy wyżej, choć na różne sposoby starał się pozytywnie mówić

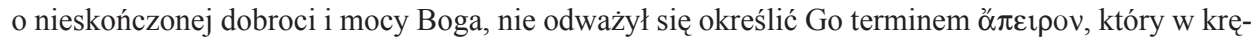
gach platońskich był zarezerwowany do opisu bezkresnej materii. 
z nich. Nie ogranicza więc Go nie tylko przestrzeń i czas, ale żadna definicja, która według Arystotelesa polega na wskazaniu genus proximum et differentia specifica $^{54}$. Bóg nie daje się zamknąć czy ograniczyć do żadnego pojęcia. Nie

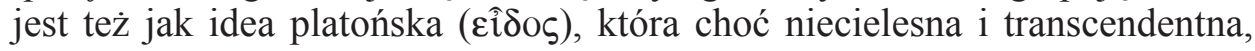
pozostaje ściśle określona, a więc i ograniczona, o czym już wspominaliśmy.

Największą jednak nowością, którą zawiera powyższy tekst, jest nowa definicja nieskończoności, która jest ewidentnym nawiązaniem, a zarazem krytyką tez filozofów ateńskich w tej właśnie kwestii ${ }^{55}$. W swym Parmenidesie ${ }^{56}$ Platon, podobnie jak teraz Klemens, stwierdza, iż Jedno nie może być całością (ő̉ov), nie może mieć żadnych części ( $\mu \varepsilon ́ \rho \circ$ ) oraz implicite, że jest niepodziel-

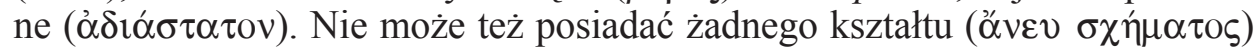

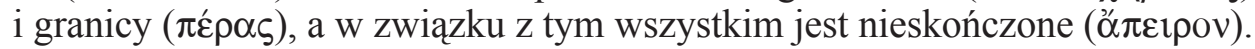
Aleksandryjczyk tylko po części zgadza się z wywodem wyłożonym w Pierwszej Hipotezie Platońskiego Parmenidesa. Rozstaje się z Platonem, gdy stwierdza, iż całość jest kategorią wielkości ( $\mu \varepsilon \gamma \varepsilon \hat{\varepsilon} \theta \varepsilon \imath$ ), podczas gdy filozof ateński dowodzi, iż całość to coś, czemu nie brak żadnej części, a częściami takiej

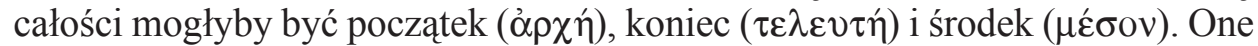
też według filozofa z Aten byłyby jej granicami. Klemens nie wchodzi w tego typu rozważania, gdyż stwierdziwszy jednoznacznie, że Bogu nie przysługują żadne kategorie fizyczne, jakimi są wielkość czy kształt, nie widzi powodu, by mówić o Jego początku, końcu czy środku. Jedno jest jednak według niego

\footnotetext{
${ }^{54}$ Por. Aristoteles, Topica 103b 15-16, ed. Bekker, vol. 1, s. 103: „ó ópıб $\delta \imath \alpha \varphi \circ \rho \hat{\omega} v \dot{\varepsilon} \sigma \tau \imath v^{\prime \prime}$.

${ }^{55} \mathrm{Na}$ temat tej właśnie definicji, a zarazem polemiki z tezami Platona i Arystotelesa por. J. Whittaker, Philological Comments on the Neoplatonic Notion of Infinity, w: The Significance of Neoplatonism, ed. R. Harris, Norfolk 1976, 155-172 oraz A. Choufrine, Gnosis, Theophany, Theosis. Studies in Clement of Alexandria's Appropriation of His Background, New York 2002, 159-197. Zob. Mrugalski, Il Dio trascendente, s. 205-210, gdzie referuję analizy wspomnianych tu uczonych. Poniższe dwie strony będą w dużej mierze opierały się na tychże analizach.

${ }^{56}$ Dla zrozumienia dalszych analiz przytoczę w tym miejscu obszerniejszy tekst dotyczący jednej z Platońskich hipotez odnośnie do Jedna. Opuszczę jednakże sformułowania związane z dialogicznym charakterem dzieła, które do całości rozumowania filozofa nic ważnego nie wnoszą. Por. Plato, Parmenides 137c-e, ed. A. Hermann: Plato's Parmenides. Text, Translation \& Introductory Essay, Las Vegas - Zurich - Athens 2010, 106-108, thum. W. Witwicki: Platon, Dialogi, t. 2, Kęty 2005, 271-272: „Jeżeli istnieje Jedno, to ono nie może być tym samym, co wiele [...]. Zatem ani część jego istnieć nie powinna, ani ono nie powinno być całością [...]. Przecież część jest chyba częścią całości [...]. A cóż całość? Czy nie prawda, że to, czemu nie brak żadnej części, to tylko może być całością? [...]. Więc z obu względów Jedno musiałoby się składać z części: i całością będąc, i części mając [...]. Więc z obu względów w ten sposób Jedno byłoby wielością, a nie czymś Jednym [...]. A trzeba, żeby to nie była wielość, tylko Jedno [...]. Zatem ani całością nie będzie, ani części mieć nie będzie, jeżeli jedno będzie Jednym [...]. Nieprawdaż? Jeśli ono nie ma żadnej części

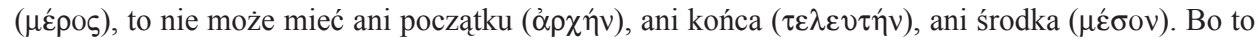
by już były jego części [...]. I prawda, że koniec i początek to granice ( $\pi \dot{\varepsilon} \rho \alpha \varsigma)$ każdej rzeczy? [...].

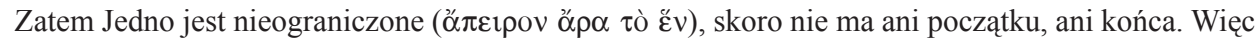

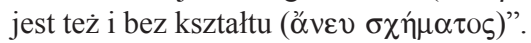


nieskończone w innym sensie ${ }^{57}$. Zanim jednak odpowie w jakim, odwołuje się jeszcze do Arystotelesowskiej definicji nieskończoności jako nieprzemierzalności ${ }^{58}$. Stwierdza bowiem, że Jedno jest nieskończone, ,nie w takim rozumie-

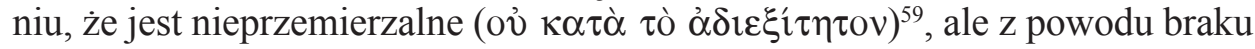
wymiaru i granicy". Według Arystotelesa byt, którego nie da się przemierzyć nie istnieje ani potencjalnie, ani aktualnie. Nieskończoność bowiem, o czym już pisaliśmy, może istnieć według Stagiryty jedynie jako funkcja pewnego procesu, a więc potencjalnie, nie zaś substancjalnie. Nieskończone może być dzielenie, nieskończone może też być następowanie po sobie zjawisk, jednakże nie rzecz w sobie (oủ $\kappa \alpha \theta^{\prime} \alpha$ $\alpha$ đó) ${ }^{60}$. Klemens zgadza się więc z Arystotelesem, że nie istnieją byty nieprzemierzalne. Bóg jednakże jest nieskończony, nie w sensie bycia nieprzemierzonym, lecz dlatego, że w ogóle nie posiada żadnego wymiaru - jest ỏ $\delta$ ı́ $\sigma \tau \alpha \tau o \varsigma$. Coś, co nie ma wymiaru, nie może też posiadać żadnej granicy ( $\pi \varepsilon \dot{\varepsilon} \rho \varsigma_{)}$). Siłą rzeczy musi więc być zdefiniowane jako ő $\pi \varepsilon ı \rho o v$, czyli ,bezgraniczne” lub ,nieskończone”. W taki oto sposób myśliciel chrześcijański z Aleksandrii formułuje pierwszą, znaną nam w historii filozofii, definicję nieskończoności Boga. Bóg, będąc niecielesnym, a więc i bezkształtnym

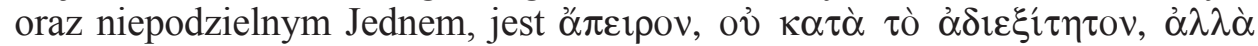

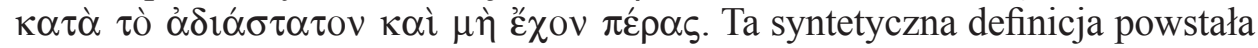
w wyniku refleksji i polemiki z tezami wielkich filozofów ateńskich, według których transcendentny Bóg nie mógł być nieskończony.

Konsekwencją nieskończoności Bożej natury, jak już to zaznaczyliśmy wyżej, przy okazji omawiania doktryny Filona, ale także Klemensa, jest absolutna niepoznawalność istoty Boga. Pomimo wielu tak radykalnych stwierdzeń w tej kwestii, myśliciel chrześcijański podaje pewną metodę rozumowania, za

${ }^{57}$ Szerzej na temat wpływów platońskiego Parmenidesa na myśl żydowską i chrześcijańską zob. D.T. Runia, Early Alexandrian Theology and Plato's „Parmenides”, w: Plato's „Parmenides” and its Heritage, vol. 2: Its Reception in Neoplatonic, Jewish, and Christian Texts, ed. J.D. Turner - K. Corrigan, Atlanta 2010, 175-187; M. Edwards, Christians and the „Parmenides ”, w: Plato's ,Parmenides” and its Heritage, vol. 2, s. 189-198; E. Osborn, Clement of Alexandria, Cambridge 2005, 111-144.

${ }^{58}$ Por. Aristoteles, Physica III 204a 2-7, ed. Bekker, vol. 1, s. 204, thum. Leśniak, s. 124: „Należy więc przede wszystkim zacząć od określenia różnych znaczeń, jakie się nadaje pojęciu nieskończoności ( $\tau$ ò ớ $\varepsilon \varepsilon i \rho o v)$. W pierwszym znaczeniu będzie nią to, co z natury swej nie może być prześledzone ( $\left.\delta \imath \imath_{\theta} \theta \varepsilon \hat{\imath} v\right)$, jak np. głos, który jest niewidzialny. Po drugie będzie nią to, co może być

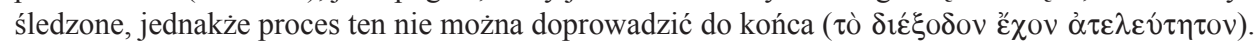
Albo to, co z trudem tylko da się prześledzić. Wreszcie to, co z natury swej może być przedmiotem

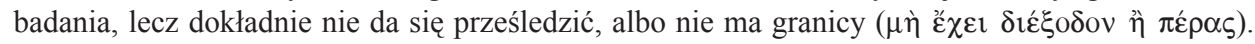
Oprócz tego nieskończone jest to wszystko, co powstaje przez dodawanie albo przez podział, albo w skutek obydwu tych czynności”.

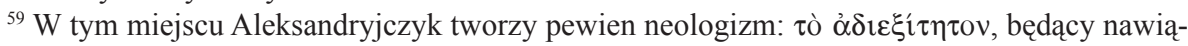

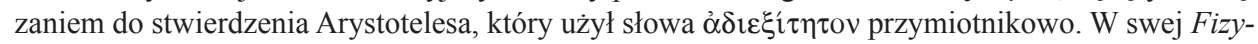

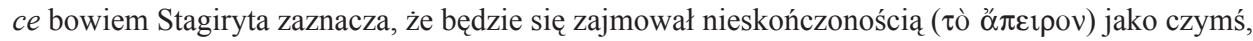

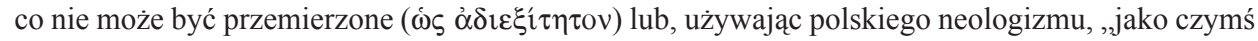
nieprzemierzalnym". Por. tamże III 204a 14, ed. Bekker, vol. 1, s. 204.

${ }^{60}$ Por. tamże III 206b 12-16. 
pomocą której każdy filozof może dojść do jakiegoś, wcale nie błędnego, pojmowania tego, czym jest Bóg. Metoda ta zostanie później określona jako via negationis. Co ciekawe, na końcu opisu tej intelektualnej procedury negacji, Aleksandryjczyk ponownie powraca do zagadnienia nieskończoności i niepoznawalności Boga, inaczej je jednak definiując niż w przytoczonym wyżej tekście. Okazuje się bowiem, iż Bóg jest nie tylko prosty i dlatego nieskończony, lecz że jest zarazem niewyczerpanym bogactwem idei, albo - mówiąc językiem biblijnym - niezgłębioną Mądrością, której skończony umysł ogarnąć nie może:

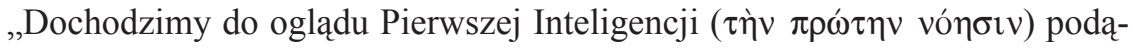
żając drogą analizy. Jej początek wyznacza analiza przedmiotów, które należy ogołocić z fizycznych jakości właściwych ciału, a mianowicie rozciagłość w głąb, rozciagłość w szerz, a następnie długość. To, co pozostaje - punkt jest monadą, która, że tak powiem, posiada jeszcze umiejscowienie. Jeśli ogołocimy ją z tego umiejscowienia, dochodzimy do właściwego pojmowania monady. Jeśli następnie pozbywając się wszystkiego, co przysługuje ciałom i tak zwanym bytom niecielesnym, przerzucimy się do wielkości Chrystusa

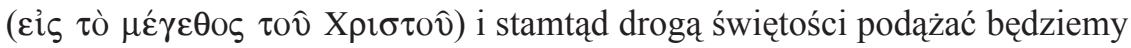

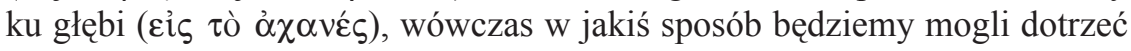

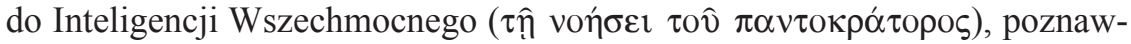

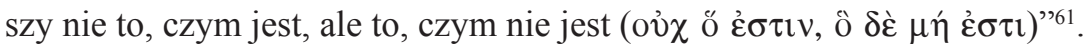

W powyższym tekście, Klemens mówiąc o Bogu posługuje się terminem

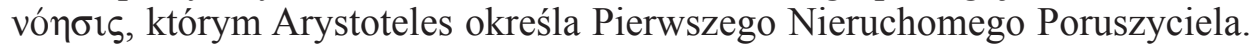
Choć dla lepszego zrozumienia tekstu przetłumaczyliśmy vó $\sigma ı \varsigma$ jako „In-

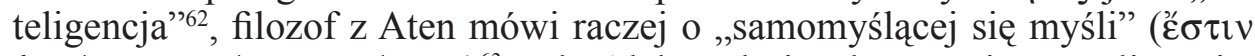

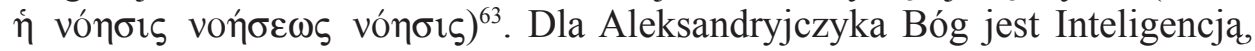
która myśli, jednakże myśli nie tylko samą siebie, lecz także świat, który stwarza za sprawą Logosu zeń zrodzonego. Ponieważ owa Boska Inteligencja jest zupełnie niecielesna, aby Ją uchwycić filozof musi podążać drogą negacji, a więc odrzucania właściwości, które przysługują bytom będącym w czasie i przestrzeni. Po wykonaniu takiej procedury, dochodzi do pojęcia ,punktu”,

\footnotetext{
${ }^{61}$ Clemens Alexandrinus, Stromata V 71, 2-4, GCS 15, 374, thum. własne.

${ }^{62}$ Thumaczka Kobierców, J. Niemirska-Pliszczyńska (Klemens Aleksandryjski, Kobierce, t. 2,

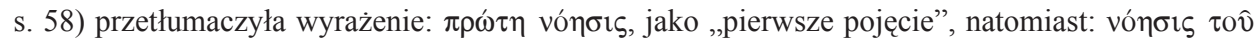

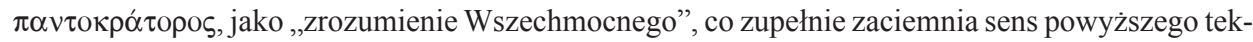
stu Klemensa, który mówi o dochodzeniu do poznania Boga będącego Inteligencją, a nie „,pojęciem”. Słowo vónбıৎ w powyższym kontekście można by przetłumaczyć również jako ,intelekt” lub „rozum", choć greckim odpowiednikiem tych dwóch polskich słów jest raczej termin vô̂s. Podczas

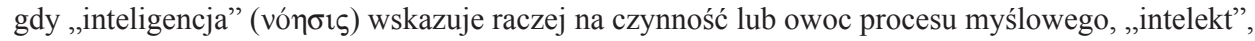
czy „rozum” (vov̂s) wskazuje na podmiot dokonujący procesu myślenia. Ponieważ w dalszej części tekstu Klemens mówi o poznawaniu tego, co jest myślane przez Boga, nie bez powodu posłużył się on terminem vónбıs, a nie vov̂s. Por. Abramowiczówna III 211. Zob. także Liddell - Scott, s. 1178.

${ }^{63}$ Por. Aristoteles, Metaphysica XII 1074b 34-35, ed. Bekker, vol. 2, s. 1074.
} 
który nie posiada już żadnej rozciągłości. Według Arystotelesa jednak, punkt matematyczny jest czymś, co nie będąc rozciągłe, posiada umiejscowienie, czyli pozycję $(\theta \dot{\varepsilon} \sigma ı)^{64}$. Aby zrozumieć, czym jest Bóg w swojej naturze, filozof powinien odrzucić również i tę kategorię. W ten sposób dochodzi do pojęcia „monady”, która nie ma ani rozciąłości przestrzennej, ani umiejscowienia, a jest czymś zupełnie prostym, niepodzielnym i niezmiennym. Droga negacji nie prowadzi jednak do zrozumienia tego, czym Bóg jest, lecz czym

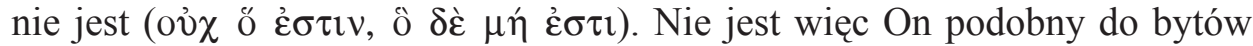
cielesnych, ale też nie jest jedynie jakimś pojęciem matematycznym. Dlatego też Klemens mówi o odrzuceniu wszelkich właściwości, które człowiek

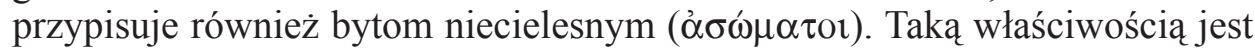
z pewnością bycie ograniczonym (zamkniętym) przez definicję. Bóg nie daje się zamknąć w żadnej definicji, gdyż, choć jest prosty, jest niezmierzoną głę-

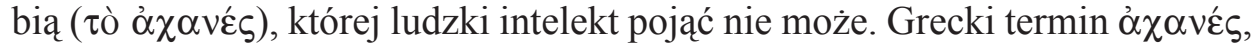
używany przez Arystotelesa do opisu czegoś niezgłębionego i niemożliwego do prześledzenia ${ }^{65}$, wskazuje u Klemensa na bezkres lub nieskończoność Boskiej wiedzy. Poznanie jej nie jest już możliwe dzięki naturalnym możliwościom ludzkiego intelektu, lecz jedynie dzięki Objawieniu dokonanemu przez Chrystusa. Mało tego, nie polega ono jedynie na intelektualnym zgłębianiu

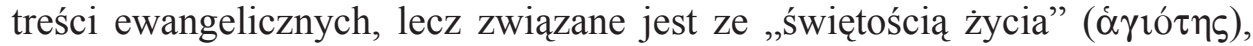
a więc $\mathrm{z}$ procesem upodobnienia się człowieka do Boga, któremu musi towarzyszyć łaska - nadprzyrodzony dar pochodzaccy od Boga ${ }^{66}$.

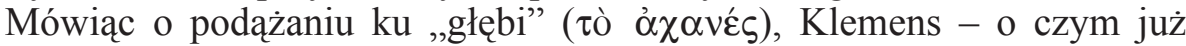
wspomnieliśmy - dochodzi do kolejnego rozumienia nieskończoności, jako nieskończonej wielkości ( $\mu \varepsilon ́ \gamma \varepsilon \theta o \varsigma)$. Nie polega już ona na nieposiadaniu wymiaru, i przez to jakiejkolwiek granicy, jak to wykazał przy okazji opisu natury transcendentnego Jedna, lecz na nieskończonej wielkości mocy i mądrości, która jest w Bogu. Ową nieskończoną mocą i mądrością, która przebywa w „łonie Ojca”, jest Logos - Boży Syn, o czym Aleksandryjczyk pisze explicite w dalszej części tekstu Kobierców:

„Apostoł Jan mówiąc: «Boga nikt nigdy nie widział, Jednorodzony Bóg, Ten, który jest w łonie Ojca, o Nim pouczył» (J 1, 18), nazwał łono Boga nie-

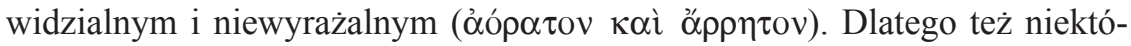
rzy nazwali je głębią ( $\beta v \theta \dot{v})$, ponieważ wszystkie rzeczy zostały ogarnięte

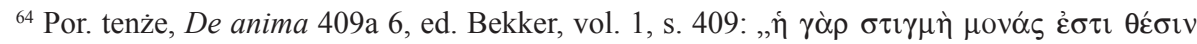

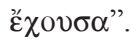

${ }^{65} \mathrm{Na}$ przykład: bezkresna przestrzeń rozciągająca się między ziemią a gwiazdami, bezkresna otchłań we wnętrzu ziemi czy też bezkres morza, którego nie można ogarnąć. Zob. tenże, Meteorologica 340a 32; 355b 31; 267a 19.

${ }^{66}$ Por. Clemens Alexandrinus, Stromata II 4, 1 - 8, 1; VI 166, 1-5. O relacji między wiedza, wiarą, miłością oraz Bożym działaniem w procesie upodobnienia się człowieka do Boga zob. tamże VII $55,1-59,7$. 


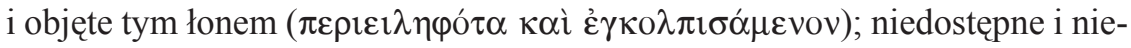

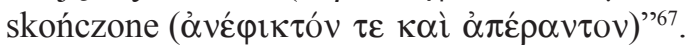

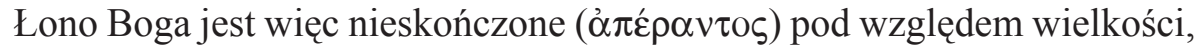
nie fizycznej oczywiście, lecz wielkości rozumianej jako ogrom i bogactwo Bożych idei i mocy ${ }^{68}$. Utożsamia się ono z Logosem Boga, bowiem Logos, Moc i Mądrość Boga ${ }^{69}$, jest wszystkim tym, co myśli i chce Ojciec ${ }^{70}$. Jest Ono

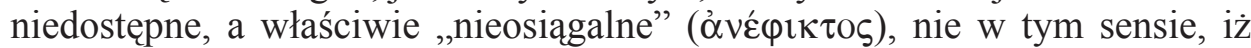
nikt nie może do Niego dotrzeć, lecz dlatego, że żaden skończony intelekt nie jest w stanie Go ogarnąć w całości. Choć Klemens nawiązuje w powyższym tekście do teologii gnostyckiej, mówiąc iż niektórzy nazywają łono Boga głębią, albo też „otchłanią” ( $\beta v \theta o ́ \varsigma)^{71}$, to bynajmniej nie potępia w tym miejscu terminu, którym posługiwali się gnostycy. Tak jak otchłań, tak Syn Boży, będąc Bożą Mądrością jest niezgłębiony, co zresztą potwierdza Pismo, na które powołuje się Aleksandryjczyk w wielu innych miejscach ${ }^{72}$.

Bóg-Jedno oraz Logos-Mądrość są więc nieskończeni pod różnym względem. Pierwszy ze względu na absolutną prostotę i niecielesność, a w związku z tym na brak jakichkolwiek granic; drugi ze względu na nieskończone bogactwo mądrości i wiedzy Boga. I jeden i drugi wymyka się jakiemukolwiek objęciu, nawet intelektualnemu: pierwszy ze względu na brak jakiegokolwiek określenia $^{73}$, drugi ze względu na nieskończoną ilość określeń, które w sobie

${ }^{67}$ Tamże V 81, 3, GCS 15, 380, tłum. własne.

${ }^{68}$ Oprócz dosłownego cytatu z Ewangelii według św. Jana, powyższy tekst Klemensa o nieskończonym „łonie Boga” może być aluzją do wypowiedzi z Księgi Hioba (Hi 36, 22-26), gdzie jest mowa o Bogu wszechmocnym i niepoznawalnym, którego dzieła są niezgłębione, a lata niepoliczo-

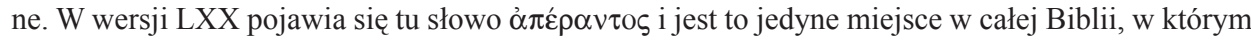

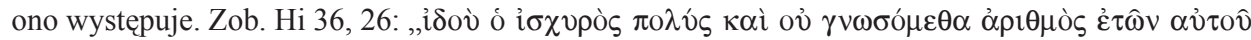

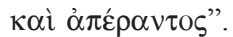

${ }^{69}$ Por. 1Kor 1, 24. Zob. Clemens Alexandrinus, Stromata I 189, 3; II 52, 7; VI 47, 3-4; VII 7, 4.

${ }^{70}$ Por. Clemens Alexandrinus, Stromata VII 5, 5 - 6, 2, GCS 17, 5-6, thum. NiemirskaPliszczyńska, t. 2, s. 220-221: „Syn Boży, nie ulegający podziałowi ani uszczupleniu, ani zmianie miejsca, lecz jest w każdym czasie wszędzie i w żaden sposób nie jest ograniczony $(\mu \eta \delta \alpha \mu \hat{n}$

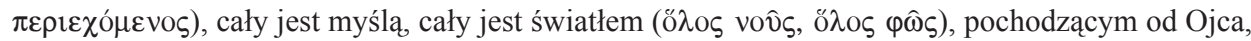

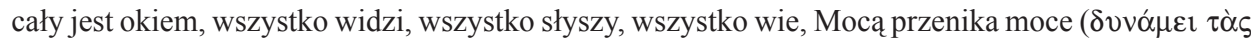

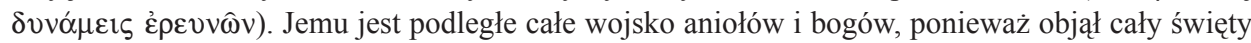
zarząd nad światem, jako Słowo pochodzące od Ojca, z woli Tego, który Mu poddał świat pod władzę. Ponadto wszyscy też ludzie należą do Niego [...]. Od Niego bierze początek Opatrzność

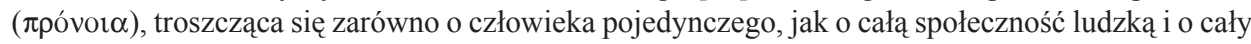
wszechświat"; tamże IV 156, 2 - 157, 2.

${ }^{71}$ Por. Irenaeus, Adversus haereses I 1, 1, ed. A. Rousseau - L. Doutreleau, t. 2: Livre I, SCh 264, Paris 1979, 28.

${ }^{72}$ Por. Rz 11, 33; 1Kor 2, 10; Ef 3, 18-19. Zob. Clemens Alexandrinus, Stromata V 80, 2-4; II 7 , 3-4; VI 166, 3. W tekstach tych, pojawia się słowo ßó日os, które w wielu przypadkach jest synonimem gnostyckiego słowa ßvӨós. Również ono oznacza głębię i otchłań zarówno w odniesieniu do rzeczywistości stworzonej, jak i w odniesieniu do Boga, por. Lampe, s. 282 i 306.

${ }^{73}$ Por. Clemens Alexandrinus, Stromata V 82, 2-4, GCS 15, 381, thum. Niemirska-Pliszczyń- 
zawiera. Tymi określeniami są Boskie idee lub moce. Każdą z nich ludzki intelekt jest w stanie w jakiś sposób uchwycić, lecz wszystkie razem są nieobejmowalne. Pisze o tym Klemens explicite w innym miejscu Kobierców, gdzie nawiązując po raz kolejny do definicji nieskończoności Arystotelesa ${ }^{74}$, stwierdza, iż Mądrość Boża, która jest Logos, jest wprawdzie możliwa do prześle-

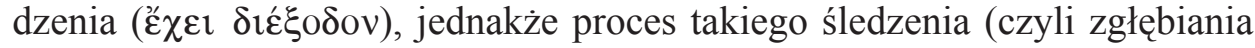
lub poznawania) nie może mieć końca ${ }^{75}$.

W innym znowu miejscu Aleksandryjczyk powie, iż poznanie Boga, do którego dąży gnostyk, czyli doskonały chrześcijanin, ,prowadzi do celu, któ-

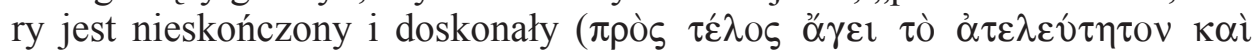
$\tau \dot{\varepsilon} \lambda \varepsilon ı v)^{\prime \prime 76}$. Pomijając fakt, że po raz kolejny pojawia się tu znana już terminologia związana ze starożytnymi definicjami nieskończoności, warto zwrócić uwagę na swoistą grę słów, którą posługuje się Klemens. Otóż cel ( $\tau \dot{\varepsilon} \lambda \circ \varsigma$ ) gnostyka, którym jest sam Bóg, jest nieskończony (ỏ $\tau \varepsilon \lambda \varepsilon v ́ \tau \eta \tau o v)$, a jednak doskonały ( $\tau \dot{\varepsilon} \lambda \varepsilon \imath o v)$. Słowo ,doskonały”, o czym już wspomnieliśmy na początku tego tekstu, oznacza dla starożytnych tyle co ,skończony”, natomiast „nieskończony” tyle co ,niedoskonały”. W swej Fizyce Arystoteles

ska, t. 2, s. 66: „Bo to, co jest przedmiotem naszej definicji, może być określone albo na podstawie cech przysługujących przedmiotowi, albo na podstawie relacji wzajemnych między przedmiotami. Niczego tego rodzaju nie można zastosować do pojęcia Boga. Również nie może być Bóg pojęty przy pomocy nauki posługującej się dowodami. Ona bowiem opiera się na przesłankach poprzedzających i lepiej znanych, a przecież nic nie mogło zaistnieć przed Niezrodzonym. Pozostaje, jako jedyna możliwość, obejmować myślą Niepoznawalne przez dar łaski Bożej i w wyłącznym oparciu o Słowo od Boga pochodzące".

${ }^{74}$ Por. Aristoteles, Physica III 204a 2-7, wyżej cytowany w całości. W drugiej z definicji nieskończoności sformułowanych w tym tekście, Arystoteles stwierdza, że nieskończonym może być

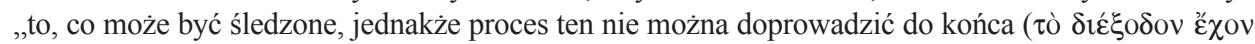

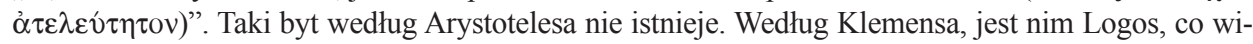
dać w niżej cytowanym fragmencie, w którym Aleksandryjczyk posłużył się terminologią Stagiryty.

${ }^{75}$ Por. Clemens Alexandrinus, Stromata IV 156, 1- 157, 1, GCS 15, 317-318, tłum. własne: „Bóg

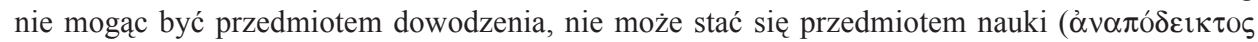

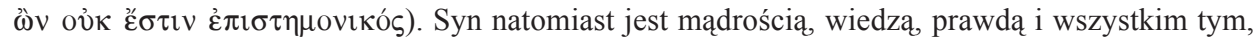
co przysługuje tym jakościom. Przysługuje Mu więc możliwość bycia przedmiotem dowodzenia

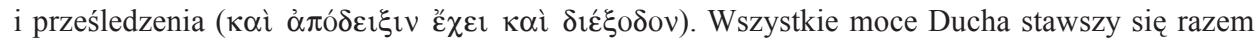
jednym bytem należą do Niego, to jest do Syna. On jednak pozostaje nieredukowalny ( $\alpha \pi \alpha \rho \varepsilon ́ \mu-$

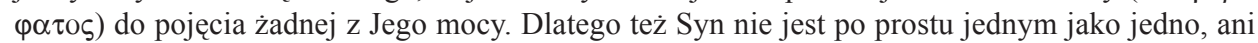

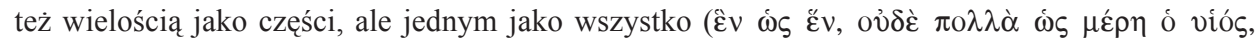

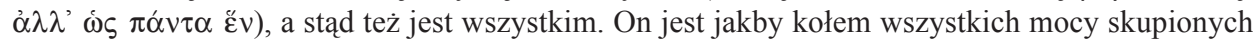
i połączonych w jedno. Dlatego też Logos jest nazwany «Alfą i Omegą», gdyż tylko w Nim koniec

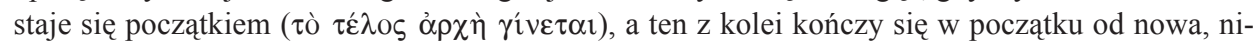
gdzie nie mając przerwy". Oprócz definicji nieskończoności Arystotelesa, o której wspomnieliśmy wyżej, Klemens odwołuje się w tym tekście do Drugiej Hipotezy z Platońskiego Parmenidesa. W Pierwszej Hipotezie bowiem - jak słusznie zauważa Choufrine (Gnosis, Theophany, Theosis, s. 174-177) - Platon mówi o „Jednym jako jedno”, w Drugiej o „Jednym jako wielości”. Por. Plato, Parmenides 143a.

${ }^{76}$ Clemens Alexandrinus, Stromata VII 56, 3, GCS 15, 41. Por. tamże II 134, 1-2. 
stwierdza, że ,nie będzie doskonałym (skończonym) w żadnym wypadku to,

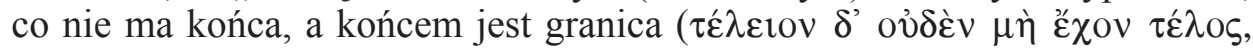

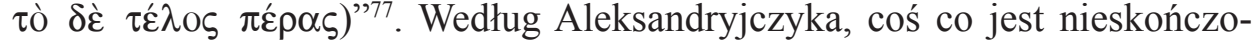

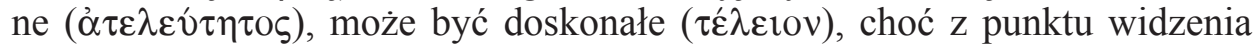
językowego zachodzi tu pewnego rodzaju sprzeczność. Doskonała bowiem, choć nigdy nie osiagająca swego celu, może być aktywność skierowana ku poznawaniu Boga ${ }^{78}$. Już bowiem akt kontemplacji, który rozciąga się w nieskończoność, a nie jego ukończenie, jest szczęściem człowieka. Doskonały, choć nieskończony, jest również sam Bóg w swej istocie i mocy, gdyż Jego nieskończoność nie odnosi się do szczęścia, któremu miałoby czegoś brakować, lecz opisuje nadmiar Dobra, które nieustannie i bezgranicznie udziela się światu. Owo udzielanie się nie musi mieć jakiegoś kresu ( $\pi \varepsilon ́ \rho \alpha \varsigma)$, a jednak może być uznane za coś doskonałego ( $\tau \dot{\lambda} \lambda \varepsilon \imath \mathrm{lov}$ ). Tak więc, obok nowej

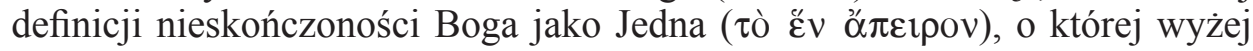

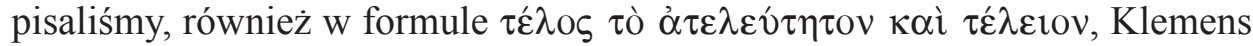
rozstaje się ewidentnie $\mathrm{z}$ dotychczasowym rozumieniem nieskończoności jako nie-doskonałości i nie-dokończoności.

3. Wątpliwe fragmenty, czy wątpliwa interpretacja? Jak zauważyliśmy we wstępie, całe „zamieszanie”, które doprowadziło historyków idei do błędnego przypisywania Plotynowi pierwszeństwa w nadaniu pojęciu nieskończoności waloru pozytywnego, wiąże się z niektórymi wypowiedziami Orygenesa, z których miałoby wynikać, że moc Boża jest w jakiś sposób ograniczona. Jednakże czy badacza zajmującego się filozofią i teologią aleksandryjską nie powinno nurtować następujące pytanie: dlaczego Orygenes, wielki i wnikliwy myśliciel, świetnie znający doktrynę Filona z Aleksandrii (który ocalił ją od zapomnienia i przekazał dalszym pokoleniom), jak i doktrynę swojego mistrza Klemensa Aleksandryjskiego, miałby odrzucać czy choćby tylko ignorować wyłożoną przez nich naukę o Bogu nieskończonym? Ponadto, dlaczego, jeśli znał tę doktrynę, nie odniósł się do niej krytycznie explicite, to znaczy, dlaczego nie wykazał jej braków, sprzeczności czy nieścisłości? Nie jest bowiem w stylu Orygenesa pomijanie tak ważnej kwestii, skoro w swoich dziełach uważnie śledzi, rozwija, a niekiedy krytykuje lub poprawia różnorakie, o wiele mniejszej wagi tezy filozoficzne, które pojawiły się w tekstach poprzedników. Jeśli jednak tego nie zrobił, to warto się przyjrzeć tym kilku

${ }^{77}$ Aristoteles, Physica III 207a 14, ed. Bekker, vol. 1, s. 207.

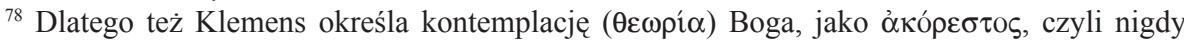
nienasyconą. Por. Clemens Alexandrinus, Stromata V 40, 1; VI 75, 1; VI 108, 1; VII 13, 1. Nie musi to oczywiście oznaczać braku, czy niedostatku szczęśliwości w przypadku dusz zbawionych, lecz wskazuje na nieustanny proces poznawania lub też odkrywania tego, czym jest nieskończony Bóg. W ten sposób również ludzkie poznanie Boga rozszerza się w nieskończoność, stając się dynamicznym i powiększającym się szczęściem dusz. 
fragmentom, na które powołują się historycy idei, i zbadać, czy rzeczywiście zostaje $\mathrm{w}$ nich odrzucona idea nieskończoności Boga ${ }^{79}$. Oto pierwszy z nich:

„Powinniśmy zatem uznać, iż na owym początku Bóg uczynił taką ilość stworzeń rozumnych albo umysłowych - czy jak tam należy nazwać byty, które określiliśmy powyżej jako umysły - jaka w Jego przewidywaniu mogła być wystarczająca. $Z$ całą pewnością Bóg je stworzył po ustaleniu ich określonej liczby; wbrew przekonaniu niektórych ludzi nie należy bowiem sądzić, że stworzenia nie mają końca, bo gdzie nie ma końca, tam nie można niczego pojąć ani określić (ubi finis non est, nec conpraehensio ulla vel circumscriptio esse potest); gdyby tak było, to stworzenia nie mogłyby być przez Boga objęte ani uporządkowane (contineri vel dispensari a deo). Wszak z samej istoty rzeczy to, co jest nieskończone, jest też niepojęte (naturaliter nempe quidquid infinitum fuerit, et inconpraehensibile erit). A przecież zgodnie ze słowami Pisma Bóg urządził wszystko «według miary i liczby» (Mdr 11, 20), i dlatego liczbę słusznie będziemy odnosić do stworzeń rozumnych lub do umysłów: jest ich tyle, iloma opatrzność Boża może kierować i rządzić oraz ile może obejmować. Miarę natomiast odniesiemy konsekwentnie do materii cielesnej: musimy wierzyć, iż Bóg stworzył ją taką, jaka w Jego przekonaniu może wystarczyć do urządzenia świata" $"$.

Przed analizą powyższego tekstu należy zaznaczyć, iż znajduje się on w księdze II dzieła $O$ Zasadach, w której Orygenes zajmuje się przede wszystkim zagadnieniami związanymi ze światem stworzonym. Traktat o Bogu, Jego naturze oraz pochodzeniu poszczególnych Osób Trójcy znajduje się w księdze

${ }^{79}$ Należy zaznaczyć, że inspiracją do napisania tej części niniejszego tekstu były dwie monografie Panayiotisa Tzamalikosa dotyczące ontologii, kosmologii i eschatologii Orygenesa, w których autor porusza również zagadnienie nieskończoności. Wydaje się, iż jest to pierwszy badacz, który odrzucając powszechne wśród historyków filozofii i teologii przekonania, zaczął mówić odważnie o obecności konceptu nieskończoności Boga w doktrynie Adamancjusza, por. P. Tzamalikos, Origen: Cosmology and Ontology of Time, Leiden 2006, 245-259; tenże, Origen: Philosophy of History \& Eschatology, Leiden 2007, 174-185. W swych analizach Tzamalikos zajmuje się czterema fragmentami tekstów Orygenesa, na które już od dziesięcioleci powołują się historycy idei, dopatrując się w nich tezy o skończoności Boga. Tzamalikos udowadnia, że owe fragmenty nie wyrażają explicite przypisywanej im tezy. Autora wspomnianych monografii interesuje jednak bardziej koncept nieskończoności Boga w czasie, a więc wieczności. Ponadto w swych poszukiwaniach odwołuje się on do myślicieli tworzących po Orygenesie, takich jak Plotyn i Grzegorz z Nyssy. Niekiedy wskazuje na orygeniańskie zapożyczenia z doktryn stoików. Choć w dalszej części tego artykułu odwołamy się również do tych samych, kontrowersyjnych fragmentów dzieł Adamancjusza, nasza analiza będzie odbiegała od tej, którą przedstawił Tzamalikos. Będziemy bowiem starali się ukazać kontynuację myśli Filona i Klemensa z Aleksandrii w doktrynie Orygenesa. Odwołamy się również do polemiki, jaką prowadzili myśliciele żydowscy i chrześcijańscy z tezami Arystotelesa na temat nieskończoności, by ostatecznie wykazać, iż według Adamancjusza Bóg jest nieskończony pod względem natury, mocy i wiedzy. Przytoczymy poniżej również te teksty, na które Tzamalikos nie zwrócił uwagi.

${ }^{80}$ Origenes, De principiis II 9, 1, ed. H. Crouzel - M. Simonetti, SCh 252, Paris 1978, 352-354, thum. S. Kalinkowski: Orygenes, O zasadach, ŹMT 1, Kraków 1996, 191 (tłum. poprawione). 
I tegoż dzieła. Tam zaś, nie dowiadujemy się właściwie niczego nowego (może wyłączając bardziej rozbudowaną argumentację), czego na temat natury Bożej nie powiedzieliby już poprzednicy Orygenesa: Filon i Klemens. Tak więc również według Adamancjusza, Bóg jest bytem niecielesnym, prostym, radykalnie transcendentnym, a przez to i niepoznawalnym. Jest określony jako intellectualis natura simplex ${ }^{81}$, co po grecku można by oddać z pewnościąjako

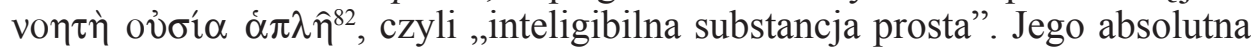
niecielesność i niezłożoność wskazują na to, iż nie ma On ani wymiaru, ani rozciągłości, ani części, a w związku z tym, nie posiada żadnej wyznaczonej granicy, kształtu czy też określonego miejsca ${ }^{83}$. Jest zarazem wszędzie i nigdzie. Charakterystyka natury Boga, jaką znajdujemy na pierwszych kartach dzieła $O$ Zasadach, w niczym nie odbiega więc od tego, co o nieskończonym Jednie, w swej definicji z Kobierców, powiedział Klemens Aleksandryjski ${ }^{84}$. Dodajmy, że również uczeń Klemensa, na określenie Boga używa terminu

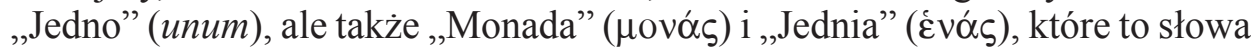
Rufin, autor łacińskiego tłumaczenia $O$ zasadach, pozostawia w języku greckim $^{85}$. Owo absolutnie proste Jedno nie może być ograniczone (circumscribi), nie tylko poprzez przestrzeń czy miejsce, których nie posiada, ale przez wszelkiego typu atrybuty, które charakteryzują skończone byty stworzone ${ }^{86}$.

${ }^{81}$ Tamże I 1, 6, SCh 252, 100.

${ }^{82}$ Podobnych pojęć na określenie natury Boga używa Adamancjusz w innych swoich dziełach, które zachowały się w języku greckim. Por. tenże, Commentarius in Joannem I 20, 119; XIX 6, 37; tenże, Contra Celsum VII 38. Termin, który Rufin przetłumaczył jako intellectualis, to po grec-

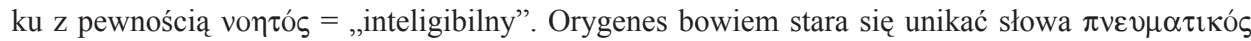
$=$ „duchowy”, ze względu na jego materialistyczne konotacje. Dla stoików przecież „duch”, czyli $\pi v \varepsilon \hat{v} \mu \alpha$, to ciało. Już na pierwszych stronach dzieła $\mathrm{O}$ zasadach Adamancjusz polemizuje z takim właśnie rozumieniem słowa „duch” i - nawiązując do tradycji platońskiej - mówi o Bogu jako o bezcielesnym Intelekcie.

${ }^{83}$ Widać to również we fragmencie, w którym Orygenes interpretuje w sposób filozoficzny spotkanie Jezusa z Samarytanką opisane na kartach Ewangelii Janowej. Kiedy Samarytanka na pytanie o miejsce kultu Boga (por. J 4, 20) otrzymuje odpowiedź, iż prawdziwy kult Boga dokonuje się w „duchu i prawdzie” (J 4, 23), autor O zasadach, komentując tę wypowiedź, stwierdza, iż kto chce iść za Bogiem, powinien odrzucić przesłanki odnoszące się do określonych miejsc (por. Origenes, De principiis I 1, 4, SCh 252, 96).

${ }^{84}$ Por. Clemens Alexandrinus, Stromata V 81, 5-6, cytowany wyżej.

${ }^{85}$ Por. Origenes, De principiis I 1, 6. Słowo $\dot{\varepsilon}$ ó́ $\varsigma=$,jednia” jest pewnego typu nowością na gruncie filozofii. Do tej pory bowiem poprzednicy Orygenesa w odniesieniu do Boga używali terminu $\check{\varepsilon} v=$,jedno". Zapewne z powodu tej oryginalności Rufin pozostawia je w języku greckim. W innych swoich dziełach jednak Adamancjusz będzie się posługiwał także terminem ěv. Por. tenże, Commentarius in Joannem I 20, 119, ed. C. Blanc, SCh 120, Paris 1966, 122, thum. S. Kalinkowski: Orygenes, Komentarz do Ewangelii wedlug św. Jana, ŹMT 27, Kraków 2003, 50: „Bóg zatem jest

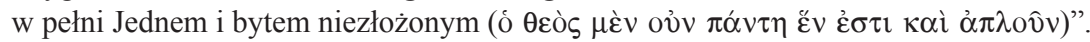

${ }^{86}$ Por. tenże, De principiis I 1, 6, SCh 252, 100, ŹMT 1, 62: „Dlatego owa niezłożona istota (natura illa simplex), która w całości jest Rozumem, w swoim ruchu i działaniu nie może się ociągać i wahać, ażeby nie wydawało się, że niezłożoność boskiej natury zawiera się i do pewnego stopnia jest ograniczona (circumscribi) w dodatkowych tego typu atrybutach; idzie o to, aby się nie 
To więc, co o naturze Boga mówi Orygenes w I księdze De principiis, ale i w wielu innych miejscach swoich pism, odpowiada poszczególnym elementom syntetycznej definicji nieskończoności Boga, którą znajdujemy w Stromatach Klemensa.

W przytoczonym powyżej fragmencie, Adamancjusz nie zajmuje się nieskończonością Boga, lecz skończonością stworzenia. Stwierdza jedynie, że Bóg stworzył określoną a więc skończoną ilość stworzeń. Z takiego stwierdzenia nie wynika jeszcze, że natura czy moc Boga są w jakiś sposób ograniczone. Orygenes zauważa po prostu, że Bóg stworzył tyle, ile chciał. W dalszej części fragmentu pojawia się polemika z filozofami utrzymującymi, iż świat, bądź liczba stworzeń w nim istniejących, jest nieskończona. Podobną polemikę znajdujemy w III księdze Fizyki Arystotelesa, gdzie filozof, krytykując poglądy swoich poprzedników, dowodzi, iż logiczna analiza pojęcia nieskończoności, musi prowadzić do wniosku, że nie mogą istnieć aktualnie nieskończone ciała, ani też nieskończona liczba aktualnie istniejących bytów materialnych ${ }^{87}$.

okazało, iż to, co stanowi początek wszechrzeczy, jest złożone i różnorodne oraz że jest wielością, a nie jednością (unum); jedność zaś, pozbawiona wszelkiej cielesnej domieszki, powinna się składać wyłącznie, że się tak wyrażę, z idei Bóstwa".

${ }^{87}$ Por. Aristoteles, Physica III 203a - 208a. Każde bowiem ciało - argumentuje Stagiryta - rozciaga się we wszystkich kierunkach. Powierzchnia jest tym, co je obejmuje, a tym samym tym, co wyznacza mu granice. Gdyby istniało aktualnie nieskończone ciało, musiałoby ono rozciagać się w nieskończoność we wszystkich kierunkach i siłą rzeczy nie mogłoby posiadać żadnej powierzchni. Gdyby bowiem posiadało powierzchnię, byłoby czymś skończonym, a nie nieskończonym. Ponadto, gdyby istniało choćby jedno nieskończone ciało, nic innego nie mogłoby istnieć oprócz niego, gdyż ono jedno byłoby rozciagnięte we wszystkich kierunkach (por. tamże III 204b). Postawienie mu jakiejś, choćby najmniejszej, granicy oznaczałoby, z punktu widzenia logiki, zaprzeczeniu jego nieskończoności. Podobnie jest z liczbą. Wprawdzie zawsze można sobie pomyśleć abstrakcyjnie liczbę większą od danej, dowodzi Arystoteles (por. tamże III 207b), to jednak nie istnieje nieskończona liczba bytów aktualnie istniejących. Nieskończony zbiór to taki, „do którego można ciągle dobierać z zewnątrz jakiś nowy element” (tamże III 207a 7-8, ed. Bekker, vol. 1, s. 207, tłum. Leśniak, s. 134). Jednakże, poza tym, co aktualnie istnieje, nie ma niczego „na zewnątrz”, chyba że to, co nie istnieje. Niebytu jednakże nie ma. To, co aktualnie istnieje, z konieczności musi więc być skończone. Ponadto - argumentuje dalej Stagiryta - to, co ma liczbę, jest przeliczalne. „Jeżeli zaś przeliczalne może być przeliczone, to również byłoby możliwe przeliczenie nieskończoności” (tamże III 204b 8-10, ed. Bekker, vol. 1, s. 204, tłum. Leśniak, s. 126). Nieskończoność jednakże ex definitione jest czymś nieprzeliczalnym. Oczywiście mogą pojawiać się - według Arystotelesa - coraz to nowe byty, które do tej pory nie istniały, ale fakt ten wskazuje właśnie na to, iż nieskończoność nie jest czymś aktualnie istniejącym, lecz pewnego rodzaju funkcją dotyczącą procesu powstawania i ginięcia. Konsekwencją bycia nieskończonym jest również bycie nieogarnionym i przez nic nieobejmowalnym. Nieskończony świat nie mógłby więc stanowić żadnej całości, nie mógłby być objęty przez żadne miejsce, ani posiadać żadnej formy. Byłby po prostu niedokończony. Całość bowiem jest tym, co obejmuje poszczególne swoje części (por. tamże III 207a); forma, jest tym, co obejmuje materię (por. tamże III 207b); a miejsce jest tym, co bezpośrednio obejmuje ciało (por. tamże III 205a - 206a). Nieskończona liczba bytów istniejących aktualnie, jako zbiór i całość, musiałaby być czymś nieuformowanym i nieistniejącym w żadnym miejscu. Nic bowiem z logicznego punktu widzenia nie jest w stanie objąć nieskończoności, ani fizycznie, ani intelektualnie. 
Do takiego właśnie rozumowania, a właściwe do wniosków wynikających z logicznej analizy pojęcia nieskończoności, nawiązuje Orygenes, kiedy stwierdza: „ubi finis non est, nec conpraehensio ulla vel circumscriptio esse potest oraz naturaliter nempe quidquid infinitum fuerit, et inconpraehensibile erit". Pojawiające się przy tej okazji słowo comprehendo ${ }^{88}$ można tłumaczyć, nie tylko jako „pojmować”, w sensie „rozumieć”, ale także jako „obejmować”. To więc, co jest nieskończone, w żaden sposób nie może być objęte, gdyż przeczyłoby to samej definicji nieskończoności, zgodnie z którą nieskończoność jest czymś nieobejmowalnym. Te ogólne stwierdzenia, powtórzone we fragmencie z De principiis II 9, 1 aż dwa razy, korespondują z wypowiedziami Arystotelesa z III księgi Fizyki. Tak więc zarówno według Arystotelesa, jak i według Orygenesa, świat aktualnie istniejący, skoro jest obejmowalny, czy to fizycznie - ma wszakże powierzchnię, miejsce i jaką́s formę - czy to intelektualnie, gdyż jest obejmowany i porządkowany przez Boga, musi być skończony zarówno w swych częściach, jak i w całości.

Z takiej logicznej analizy pojęcia nieskończoności nie wynika jednakże, że Bóg w swej naturze jest skończony. Mało tego, Orygenes stwierdza wprost, że pojęcia „liczba” (numerus) i „miara” (mensura) odnoszą się kolejno do stworzeń i do materii, nie do Boga. Nie wynika też z powyższego tekstu, że Bóg nie może powoływać do istnienia coraz to nowych bytów, gdyż Jego moc jest ograniczona. W rzeczywistości bowiem Bóg, będąc nieskończoną aktywnością, nieustannie może stwarzać rzeczy nowe i nimi władać ${ }^{89}$. Na tym polega Jego wszechmoc, a więc niczym nieogarniona moc stwarzająca, wszystkim rządząca i wszystko obejmująca. Za każdym jednak razem Bóg powołuje do istnienia skończone byty i za każdym razem zna ich liczbę. Mało tego, na podstawie swojej wszechwiedzy Bóg uprzednio zna liczbę wszelkich istniejących bytów, również tych, które mają zaistnieć w przyszłości ${ }^{90}$. Gdyby liczba owych bytów była nieskończona, Bóg nie mógłby ich objąć (gdyż logika podpowiada, że nieskończoność jest nieobejmowalna), a wówczas można by

${ }^{88} \mathrm{~W}$ wydaniu krytycznym (SCh 252, 352) występuje lekcja: conpraehendo.

${ }^{89}$ Por. Origenes, De principiis III 5, 3, ed. Crouzel - Simonetti, SCh 268, Paris 1980, 222, ŹMT 1, 303: „Określenie Boga jako istoty bezczynnej i nieruchomej jest równocześnie bezbożnością i absurdem, podobnie zresztą jak pogląd, że kiedyś dobroć nie czyniła dobrze, a wszechmoc nie sprawowała władzy". Z tego powodu Orygenes wysuwa hipotezę istnienia następujących po sobie światów. Liczba tych światów jest jednak skończona, gdyż nieskończoność znowu prowadziłaby do wniosku, iż Bóg nie mógłby ich wszystkich poznać. Por. tenże, Commentarius in Matthaeum XIII 1. Nieskończone są jednak dobrodziejstwa, których Bóg udziela skończonej, choć ciągle powstającej w czasie, liczbie stworzeń. Jest On bowiem Dobrem, do którego natury należy nieustanne udzielanie się. Por. tenże, De principiis I 3, 7-8; I 4, 3; IV 4, 8-9; tenże, Commentarius in Joannem VI 36, 181; VI 57, 295.

${ }^{90}$ Oczywiście Bóg, będąc wszechwiedzącym, zna również liczbę stworzeń, które powoła do istnienia w przyszłości. Por. tenże, De principiis I 4, 4, SCh 252, 170, ŹMT 1, 96: „W tej więc Mądrości, która zawsze była z Ojcem, zawsze tkwiło określone i ukształtowane stworzenie, i nie było nigdy takiego momentu, w którym Mądrość nie posiadała uprzednio utworzonych idei istot mających zaistnieć w przyszłości”. 
stwierdzić, iż Bóg nie zna swojego stworzenia i nie jest w stanie nim rządzić - co dla Orygenesa jest oczywistym absurdem. Założenie istnienia nieskończonego świata stworzeń implikowałoby więc z konieczności wykluczenie konceptu Bożej wszechmocy i Bożej wszechwiedzy, na co Adamancjusz zgodzić się nie chce. Na początku więc, o którym pisze autor $O$ zasadach, Bóg stworzył skończoną, nie zaś nieskończona, liczbę stworzeń i to nie tylko dlatego, że tak twierdzi autorytet Pisma, lecz także dlatego, że wymaga tego logika Arystotelesa, a z odrzucenia której wynikałby absurdalny obraz Boga: Boga nie będącego w stanie zapanować nad tym, co sam stworzył ${ }^{91}$.

Stwierdzając, że to, co jest nieskończone, nie może być przez nic ogarnięte, Adamancjusz zgadza się również z tym, czego dowodzili jego poprzednicy Filon i Klemens, twierdząc, że Bóg będąc nieskończony, pozostaje niepoznawalny w swej istocie. O niepoznawalności Bożej natury pisze Orygenes w I księdze $O$ zasadach ${ }^{92}$ i bynajmniej teraz, w księdze II, nie podważa tego, co wcześniej napisał. Zdanie ,ubi finis non est, nec conpraehensio ulla vel circumscriptio esse potest" nie powinno więc prowadzić do wniosku, że Bóg nie może być nieskończony, gdyż nie mógłby poznawać samego siebie. Postuluje ono natomiast tezę, że obok Boga nie może istnieć żaden inny nieskończony, a więc nieobejmowalny przez Niego byt. W przeciwnym razie Bóg nie mógłby być Bogiem, czyli kimś, kto wszystko ogarnia, wszystkim włada i wszyst-

${ }^{91}$ Pisze o tym Adamancjusz explicite również w innym miejscu. Por. Origenes, De principiis III 5, 2, SCh 268, 220-222, ŹMT 1, 302: „A jeśli istnieje ktoś, kto sprzeciwiłby się tutaj powadze lub świadectwu naszego Pisma, zapytamy go, czy uznaje, że Bóg może ogarnąć wszystko, czy nie może? Stwierdzenie - «nie może» - stanowi jawią bezbożność. Jeśli przeto powie z konieczności, że Bóg ogarnia wszystko, to już samo to, iż wszystko może zostać ogarnięte, wystarcza, abyśmy uznali, że ma ono początek i koniec. To bowiem, co wcale nie ma początku, żadną miarą ogarnięte być nie może. Bo choćby pojmowanie mogło się rozciągnąć bardzo daleko, to jednak możliwość ogarnienia umyka i oddala się nieskończenie tam, gdzie początku nie ma". Zaznaczmy, iż jest to kolejny fragment, na który powołują się historycy idei sugerując, iż Orygenes podzielał pogląd starożytnych dotyczący negatywnego rozumienia nieskończoności. Jak widać, nie znajdujemy w nim żadnych nowych danych, niż te, o których już pisaliśmy wyżej a propos fragmentu De principiis II 9, 1, z tym może wyjątkiem, że jeszcze bardziej zostaje tu podkreślona ,absurdalność” mówienia o nieskończonym lub niestworzonym świecie. Gdyby świat nie był stworzony przez Boga - argumentuje Orygenes - to znaczy, gdyby nie miał jakiegoś początku lub gdyby liczba stworzeń była nieskończona, Bóg nie mógłby być Bogiem. Nie mógłby bowiem objąć nieskończonego ex definitione. Co nie oznacza oczywiście, iż Jego natura czy moc jest skończona. Mało tego, stwierdzając, iż „to, co wcale nie ma początku, żadną miarą ogarnięte być nie może”, wskazuje również w pewien sposób na Boga. To przecież Bóg jest - według niego - bez jakiegokolwiek początku. To On więc nie może być przez nic ogarnięty, w przeciwieństwie do swego stworzenia.

${ }^{92}$ Por. tamże I 1, 5, SCh 252, 98, ŹMT 1, 61: „Skoro więc w miarę naszych możliwości wykazaliśmy bezsens myślenia o Bogu jako o jakiejś istocie cielesnej, stwierdzamy zgodnie z prawdą, że Bóg jest bytem niepojętym i niezgłębionym. Cokolwiek bowiem możemy pomyśleć albo wyobrazić sobie o Bogu, musimy koniecznie uznać, że przekracza On wszelkie nasze o Nim wyobrażenie [...]. Jego istoty nie może przecież zrozumieć ani wyobrazić sobie ludzki umysł, choćby był najczystszy i najjaśniejszy". 
ko wie. W cytowanym wyżej fragmencie z De principiis II 9, 1, Orygenes stara się więc wyeksplikować, na czym polega podstawowa różnica między Bogiem a stworzeniem, a nie stwierdzić, iż moc Boga jest skończona, z tego tylko powodu, że stworzyła skończoną liczbę bytów. Stworzenie ma swój początek, miarę i liczbę, a więc pewne granice, które wyznaczył mu Bóg. On sam natomiast nie posiada żadnej z tych właściwości, gdyż to On wszystko obejmuje i wszystkim włada, nie będąc przez nic ogarniony lub ograniczony.

Dla potwierdzenia naszej tezy pomocny okazuje się także drugi fragment, na który również powołują się historycy idei postulujący u Orygenesa doktrynę o istnieniu skończonej mocy Boga:

,[Bóg] uczynił wszystko w liczbie i mierze; nic bowiem nie jest dla Boga bez końca albo bez miary. Albowiem mocą swoją obejmuje wszystko, a sam nie został objęty umysłem żadnego stworzenia (virtute enim sua omnia conpraehendit, et ipse nullius creaturae sensu conpraehensus est). Natura ta jest bowiem znana tylko sobie samej (soli sibi cognita est). Bo tylko Ojciec zna Syna i tylko Syn zna Ojca, i tylko Duch Święty przenika nawet głębokości Boże (perscrutatur etiam alta dei) ${ }^{\prime 93}$.

W tekście tym zostaje jasno stwierdzone to, o czym pisaliśmy wyżej, to znaczy, że moc Boża, jest tym, co wszystko ogarnia, a zarazem czymś, co przez nic nie może być ogarnione. Również u Filona i Klemensa, co pokazaliśmy we wcześniejszym paragrafie, znajdujemy tę samą tezę. Moc Boga, tak jak i sam Bóg, jest $\pi \varepsilon \rho t \varepsilon ́ \chi \omega \nu$, o $\pi \varepsilon \rho \imath \varepsilon \chi o ́ \mu \varepsilon v o \varsigma$ („,ogarniający, lecz nieogarniony”). Teza aleksandryjskich poprzedników Orygenesa, zostaje sformułowana właśnie w kontekście zagadnienia nieskończoności Boga. Dokładnym odpowiednikiem greckiego: $\pi \varepsilon \rho t \varepsilon ́ \chi \omega \nu$, o $\pi \varepsilon \rho 1 \varepsilon \chi o ́ \mu \varepsilon v o \varsigma$ jest łacińskie: conpraehendit, nullius conpraehensus est, które znajdujemy w thumaczeniu Rufina. Stworzenie, ze względu na swoją skończoność może więc być ogarnięte, czy też poznane, lecz nie dotyczy to nieskończonego Boga, który przez nic nie może być ogarniony. Skończony intelekt nie jest w stanie objąć nieskończoności, właśnie ze względu na swoją skończoność, a więc i ograniczoność. Pojawia się jednak pytanie, czy Bóg, skoro jest nieskończony, może poznać samego siebie? Odpowiedź Orygenesa jest pozytywna. On, i tylko On jest w stanie poznać siebie samego (soli sibi cognitus est). Boskie poznanie dotyczące własnej natury nie jest jednak poznaniem definicyjnym, czyli nie polega na zamykaniu w pojęciu tego, co uchwycone, jak to czyni ludzki intelekt. Jest ono raczej, jak sugeruje Adamancjusz powołujący się na autorytet Pisma, przenikaniem lub też intelektualnym przemierzaniem (perscrutatio) nieskończonej „głębi”, jaką jest Bóg. W tym

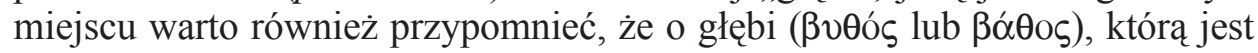
Boża Mądrość, mówił również Klemens, który uważał, że nikt, z wyjątkiem Boga samego, nie jest w stanie przemierzyć Jej bezmiaru. Stąd też wyprowadził tezę o nieskończonym procesie poznawania i upodobniania się człowieka

${ }^{93}$ Tamże IV 4, 8, SCh 268, 420, ŹMT 1, 387. Por. J 10, 15; 17, 25; 1Kor 2, 10. 
do Boga. Orygenes czyni podobnie. Powołując się w innym miejscu na tekst Rz 11, 33, w którym jest mowa o „głębokości bogactw, mądrości i wiedzy Boga

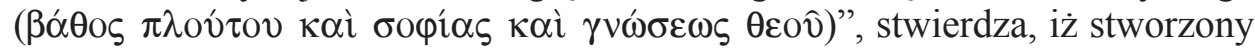
intelekt, choćby był wspomagany łaska, zawsze będzie odkrywał w Bożej Mądrości coraz to nowe tajemnice do zgłębienia, oraz że ostatecznie, choćby zrozumiał wiele z nich, nigdy nie osiagnie kresu swych poszukiwań ${ }^{94}$. Dzieje się tak dlatego, ponieważ Adamancjusz, kontynuując myśl swoich poprzedników, afirmuje nieskończoność Mocy i Mądrości Boga, którąjest Logos. On bowiem, w odróżnieniu od Ojca, czyli absolutnie prostej Zasady wszystkiego, jest wielością: wielością Jego myśli i idei. Wielość ta jednak, choć nieskończona, stanowi jedność tak, że nie można w Logosie wyróżnić jakichkolwiek części. Jest On wszystkim tym, co myśli Ojciec ${ }^{95}$.

Z analizy powyższych tekstów, na które powołując się historycy idei twierdzą, że Orygenes, będąc zanurzony w myśli helleńskiej, głosił tezę o skończonej mocy Boga ${ }^{96}$, wynika coś zgoła przeciwnego. Prawdą jest, że Orygenes jest myślicielem, który czerpie z osiągnięć filozofii greckiej, jednakże, robi to o tyle, o ile rozstrzygnięcia pogańskich filozofów nie stawały w sprzeczności z prawdami objawionymi. Odwołuje się więc do logicznej analizy pojęcia nieskończoności dokonanej przez Arystotelesa, by razem z nim stwierdzić, że nie może istnieć aktualnie nieskończona liczba bytów stworzonych. Razem z filozofem z Aten uważa również, że nieskończoność jest czymś, czego nie można objąć. Do analiz Arystotelesa dodaje jednakże wątek teologiczny zauważając, że tego, co nieskończone, nawet Bóg nie mógłby objąć. Nie wyprowadza jednakże z tego stwierdzenia tezy, iż sam Bóg jest skończony. W odróżnieniu od Stagiryty, a jednomyślnie z Filonem i Klemensem, uważa bowiem, że to

\footnotetext{
${ }^{94}$ Por. Origenes, De principiis IV 3, 14.

${ }^{95}$ Por. tenże, Commentarius in Joannem I 34, 243-251; II 18, 124-128; tenże, Philocalia V 4.

${ }^{96}$ Jest jeszcze jeden fragment, na który powołują się patrolodzy w interesującej nas kwestii. Nie dowiadujemy się jednakże z niego niczego nowego, poza tym, co już wyżej zostało stwierdzone: świat musi mieć swój początek i koniec, gdyż w przeciwnym razie nie mógłby być objęty, czyli poznany przez Boga. Por. tenże, Commentarius in Matthaeum XIII 1, ed. E. Klostermann - E. Benz, GCS 40, Leipzig 1935, 176, thum. K. Augustyniak: Orygenes, Komentarz do Ewangelii wedtug św. Mateusza, ŹMT 10, Kraków 1998, 158: „Tym, co odważyli się sądzić, iż świat się nie skończy, powiemy jeszcze i to: jeśli świat się nie skończy, lecz będzie istniał w nieskończoność, Bóg nie będzie tym, który wie wszystko, zanim się stanie (por. Dn 13, 42). Lecz może po części będzie wiedział albo o każdej rzeczy zanim się stanie, albo o niektórych, a po nich znowu o innych; niezmierzonych bowiem z natury rzeczy nie można ogarnąć wiedzą, która zwykle ogranicza wszystko, co poznaje. $\mathrm{Z}$ tego wynika również niemożliwość proroctw, dotyczących jakichkolwiek wszystkich spraw, ponieważ wszystkie sprawy są niezmierzone". Warto może jedynie podkreślić przy tej okazji, że fragment ten znajduje się w szerszym kontekście, w którym Orygenes polemizuje z greckim konceptem wędrówki dusz oraz z konceptem nieskończonego trwania zmieniającego się świata. Adamancjusz odrzuca te właśnie teorie, lecz nie dotyka zagadnienia natury Boga, który w odróżnieniu od świata trwa wiecznie, a więc nie ma początku ani końca. Por. tenże, De principiis I 2, 11, SCh 252, 138, ŹMT 1, 77: „W ścisłym znaczeniu wiekuiste i wieczne jest to, co istnieje bez początku i nie może przestać być tym, czym jest".
} 
Bóg wszystko obejmuje, sam przez nic nie będąc objęty. W ten sposób odrzuca jedynie koncept istnienia drugiego, obok Boga, nieskończonego absolutu, którym miałby być stworzony świat. Ten ostatni jest skończony, to znaczy ma swój początek i będzie miał koniec. Na tym właśnie polega zasadnicza różnica między stworzeniem a Bogiem. Orygenes, ponadto, również w odróżnieniu od Arystotelesa, a w oparciu o objawienie i tezy swoich żydowskich i chrześcijańskich poprzedników, zauważa, że Bóg jest Dobrem nieustannie udzielającym się. Swoje dobrodziejstwa udziela, według możliwości przyjmujących je stworzeń, ale z tego faktu wcale nie wynika ograniczoność Jego mocy. Jego absolutna niecielesność i transcendencja zakłada brak jakiejkolwiek granicy. Nie posiada On żadnych fizyczno-przestrzennych wymiarów, jakichś określonych atrybutów czy nawet własnej formy. Dlatego też, aby nic, nawet kategorie metafizyczne nie mogły ograniczać nieskończonej natury Boga, Orygenes, podobnie jak Filon i Klemens, powie, że Bóg jest ponad substancją ${ }^{97}$, jeśli substancję rozumie się jako coś, co jest zamknięte przez jakąś formę.

4. Przyczyny nieporozumienia i kontrowersyjny termin óx ka jest zapewne przyczyn, dla których historycy idei twierdzą, iż Plotyn był pierwszym myślicielem, który w sposób pozytywny mówił o nieskończoności Boga. Pierwszą z nich jest zapewne przypuszczenie, że brak jednoznacznych wypowiedzi Orygenesa w tej kwestii jest rezultatem braku jakichkolwiek wcześniejszych rozważań o nieskończoności Boga na gruncie chrześcijańskim. Jest tak pewnie dlatego, ponieważ nie wszyscy komentatorzy dzieł Adamancjusza szczegółowo analizują myśl jego poprzedników. Ponadto, badacze starożytnej filozofii pogańskiej nie zawsze zajmują się myślą chrześcijańską tego okresu do tego stopnia (a niekiedy ją ignorują z zasady), by dostrzec, iż przed Plotynem toczyła się bardzo subtelna dyskusja wokół pojęcia nieskończoności wśród tych, którzy uwierzyli w prawdy objawione i je komentowali. Z drugiej strony, badacze starożytnej teologii chrześcijańskiej, nie zawsze są w stanie wystarczająco wyraźnie dostrzec niektóre subtelne aluzje do wypowiedzi filozofów pogańskich, które pojawiają się w tekstach pierwszych chrześcijan. Przyjmuje się raczej pewne ogólne platońskie, arystotelesowskie lub stoickie schematy, w świetle których rozwiązuje się ewentualne aporie pojawiające się przy analizie poszczególnych tekstów Ojców Kościoła. Skoro Orygenes był platonikiem - postuluje np. Charles Bigg, wyżej cytowany - musiał traktować nieskończoność, jako zło, co potwierdzają (nie wprost oczywiście) aporetyczne fragmenty jego tekstów ${ }^{98}$.

Ponadto, w przypadku dzieła Orygenesa, zwycięża niekiedy przekonanie, iż greckie fragmenty tekstu $O$ zasadach, przekazane w relacjach innych starożytnych pisarzy, są bardziej wiarygodne, niż łacińskie tłumaczenie całości

${ }^{97}$ Por. tenże, Commentarius in Joannem XIX 6, 37; tenże, Contra Celsum VI 64; VII 38. Szerzej na ten temat zob. Mrugalski, Metamorfozy platońskiej ,,metafory stońca” [w druku], por. przypis nr 36.

${ }^{98}$ Por. Bigg, The Christian Platonists of Alexandria, s. 159. 
dzieła dokonane przez Rufina. Dla przykładu, Paul Koetschau, autor edycji krytycznej De principiis ${ }^{99}$, postanowił nawet zastępować łaciński tekst Rufina, na którym opiera się jego wydanie, fragmentami zachowanymi po grecku, $\mathrm{i}$ to nawet takimi, które wyszły spod pióra starożytnych oskarżycieli Orygenesa. I tak, we fragmencie, który wyżej analizowaliśmy (De principiis II 9, 1), choć w tekście łacińskim, nie ma mowy o skończonej mocy Boga, we fragmencie greckim, pochodzącym z Listu do Menasa cesarza Justyniana, wyraźnie zostaje stwierdzone, iż moc Boga jest skończona $(\pi \varepsilon \pi \varepsilon \rho \alpha \sigma \mu \varepsilon \dot{\varepsilon} \nu \eta)$. Ponadto, zostaje dołączone zdanie uzasadniające taką tezę: „Gdyby bowiem moc Boża

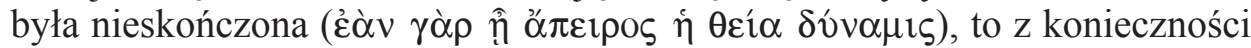
nie mogłaby pojąć sama siebie: wszak z samej natury to, co nie ma granic,

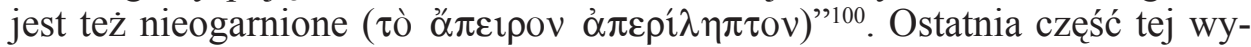
powiedzi, jak pokazaliśmy wyżej, jest zgodna z tym, co twierdził Arystoteles i sam Orygenes na temat nieskończoności. Natomiast zdanie mówiące o tym, iż Bóg nie mógłby poznać samego siebie, gdyby był nieskończony, nie koresponduje z żadną z oryginalnych wypowiedzi Adamancjusza, ani też z żadną tezą jego żydowskich i chrześcijańskich poprzedników. Czyżby to wtrącenie dorzucił sam Justynian lub wymyślił któryś z wcześniejszych oskarżycieli Orygenesa $^{101}$, a cesarz tylko je powtórzył? Również Crouzel i Simonetti, jak i zresztą sam Koetschau, mają poważne wątpliwości co do wiarygodności tego fragmentu ${ }^{102}$. Niemniej jednak, w swym komentarzu do wydania krytycznego De principiis przyznają rację właśnie Justynianowi. Powołując się bowiem na cytowaną wcześniej tezę oxfordzkiego filozofa Charlesa Bigga, jak i na inne monografie dotyczące konceptu nieskończoności w starożytności, konkludują, iż Orygenes podzielał pogląd greckich filozofów.

Stwierdzając, iż Orygenes odziedziczył negatywne rozumienie nieskończoności od Greków, Crouzel i Simonetti chcą potwierdzić swoją tezę nie tylko opinią innych badaczy, lecz także tekstami źródłowymi. W tym celu, lakonicznie odsyłają do innych miejsc w dziele Adamancjusza, w których rzekomo pojawia się teza o skończoności Boga, a które to miejsca w niniejszym tekście już przytaczaliśmy. Fragmentów tych jednak w żaden sposób nie analizują. Chociaż ich uwadze nie umyka fakt, że w dziele De oratione, zachowa-

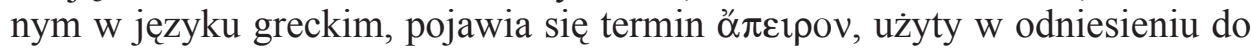

\footnotetext{
${ }^{99}$ Por. Origenes Werke, vol. V: De principiis, ed. P. Koetschau, GCS 22, Leipzig 1913.

${ }^{100}$ Justinianus Imperator, Epistula ad Mennam Constantinopolitanum, Mansi IX $489=$ Origenes, De principiis II 9, 1, GCS 22, 164, ŹMT 1, 205.

${ }^{101} \mathrm{~W}$ rzeczywistości bowiem jesteśmy w posiadaniu podobnej, choć nie takiej samej wypowiedzi pojawiającej się u Teofila z Aleksandrii. Por. Theophilus Alexandrinus, Epistula Paschalis 2, 17, w: Hieronymus, Epistula 98, 17. We fragmencie tym jest mowa o tym, że Bóg stworzył tyle bytów, ile mógł sobie podporządkować, iloma mógł władać i ile mógł objąć. Wypowiedź przytaczana przez Teofila nie pokrywa się jednak dokładnie ani z tą, którą znajdujemy u Justyniana, ani z thumaczeniem łacińskim Rufina.

${ }^{102}$ Por. Crouzel - Simonetti, nota 2, w: SCh 253, 211-213; M. Simonetti, nota 3, w: Origene, I principi, Torino 1979, 316-117.
} 
Boga, wysuwają jednak hipotezę, iż po 10 latach od napisania De principiis, Adamancjusz mógł zmienić swój pogląd ${ }^{103}$. Warto więc przytoczyć ten tekst w całości i zbadać, czy znajduje się w nim jakaś nowość, w stosunku do tego, co już wyżej stwierdziliśmy:

„Kto modli się dzisiaj do Boga, będącego od nieskończoności w nieskończo-

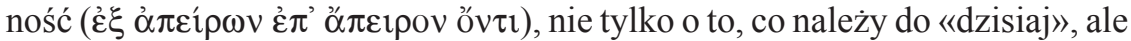
także w pewien sposób o potrzeby «każdego dnia», będzie mógł otrzymać, od Tego, który może udzielić «więcej niż prosimy czy rozumiemy», żeby powiedzieć hiperbolicznie: i więcej, niż to, «co oko nie widziało», i więcej niż to, «co ucho nie słyszało», i więcej niż to, «co nie weszło w serce człowieka»" 104 .

Według Crouzela i Simonettiego, powyższy fragment, w którym na określenie nieskończoności pojawia się techniczny termin ớ $\varepsilon ı \rho o v$, wskazuje jedynie na nieskończoność Boga w czasie ${ }^{105}$. Badacze ci nie zauważają jednakże tego, że zarówno w tym, jak i w tekście go poprzedzającym, jest mowa o nieustannym udzielaniu się Boga i o Bożych darach, które przewyższają możliwości przyjmującego je człowieka. Z tego właśnie powodu Orygenes trzykrotnie przerywa cytowany przez siebie passus biblijny z 1 Kor 2,9 , i wprowadza wy-

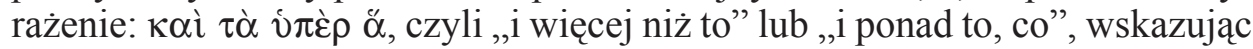
przez to na nadmiar Bożych darów, których skończone stworzenie nie jest W stanie ogarnąć czy zrozumieć. Nieco wcześniej natomiast, stwierdza razem z Pawłem, iż Bóg nie tylko w tym wieku, ale i w przyszłych, będzie ukazywał

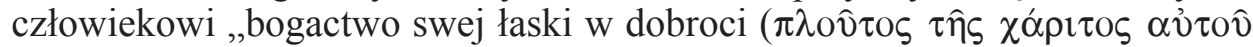

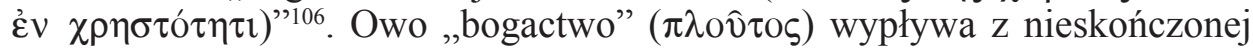
głębi (ßó日os) mądrości i wiedzy Boga, której nic nie jest w stanie przemierzyć czy objąć ${ }^{107}$. Tak więc, według Orygenesa, podobnie jak według Filona i Klemensa, o czym już pisaliśmy wyżej, Dobro, którym jest Bóg, charakteryzuje się nadmiarem. Ten właśnie nadmiar, który przekracza możliwości przyjmującego Boże dary stworzenia, a także nieprzerwana aktywność udzielającego się Dobra, która nie ma ani początku, ani końca, wskazują na nieskończoność Bożej natury pod względem ontologicznym, nie tylko zaś czasowym.

Wśród zachowanych w języku greckim pism Orygenesa, znajdujemy jed-

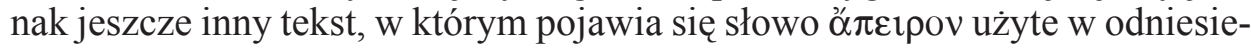
niu do Boga, na który wspomniani badacze nie zwrócili uwagi:

„O kim więc, Grecy, powiemy, że jest ślepy, jeśli nie o tych, którzy wśród tak wspaniałych i pięknych rzeczy na świecie nie potrafią wznieść oczu i stwier-

${ }^{103}$ Por. Crouzel - Simonetti, nota 2, w: SCh 253, 213.

${ }^{104}$ Origenes, De oratione XXVII 16, ed. P. Koetschau, GCS 3, Leipzig 1899, 375, thum. własne. Teksty biblijne, do których czyni tu aluzje Orygenes, są następujące: Mt 6, 11; Łk 11, 3; Ef 3, 20; 1 Kor 2, 9.

${ }^{105}$ Por. Crouzel - Simonetti, nota 2, w: SCh 253, 213.

${ }^{106}$ Origenes, De oratione XXVII 15, GCS 3, 374. Por. Ef 2, 7.

${ }^{107}$ Por. tenże, De principiis IV 3, 14. 
dzić, że należy adorować, podziwiać i czcić jedynego Stwórcę tych rzeczy, że żadne wytwory rąk ludzkich używane w kulcie bogów nie powinny być przedmiotem czci ani bez Boga Stworzyciela, ani razem z Nim? Porównywanie bowiem rzeczy zupełnie nieporównywalnych z Tym, który nieskończenie

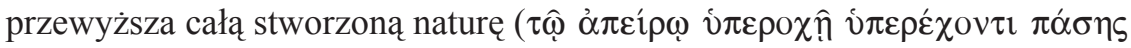

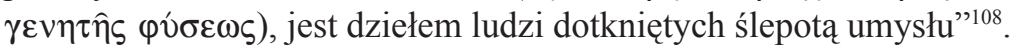

Polemika, jaką prowadzi tu Adamancjusz, z tymi, którzy oddają kult statuom bogów, sprowadza się do prostego stwierdzenia: wytwory rąk ludzkich są pewną ograniczoną, a więc skończoną materią, która nie jest w stanie zamknąć niematerialnego i transcendentnego Boga. Jego natura bowiem

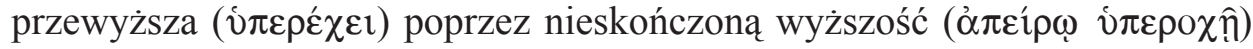

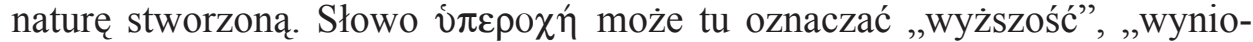
słość”, ale i „nadmiar”. Nie trzeba przypominać, że mówiąc o „wyższości” Boga względem stworzenia, Orygenes nie ma na myśli jakiejś wielkości czy odległości fizycznej, co dobitnie wykazał w I księdze dzieła $O$ zasadach, jak zresztą i w wielu innych miejscach. Wyrażenie ő odnosić się do ontologicznej, to znaczy dotyczącej natury, „wyższości” Boga. Może więc wskazywać na nieskończony „nadmiar”, którym charakteryzuje się nieustannie udzielające się Dobro, którego aktywność nie ma ani początku, ani końca lub na fakt, że to Bóg obejmuje swą mocą wszystko, sam nie będąc przez nic objęty ${ }^{109}$.

$\mathrm{Na}$ koniec chcemy przytoczyć jeszcze jedną wypowiedź Orygenesa,

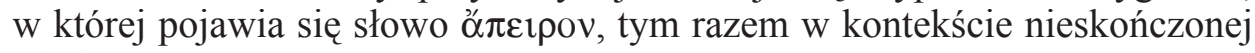
wiedzy Boga:

„Powiedzmy najpierw, że jeśli wierzymy, iż Umysł Boży jest tak wielki, aby objąć całą wiedzę o każdym istnieniu i w swojej boskości nie pominąc nawet pozornie byle jakiej, i zdawałoby się, najmniejszej rzeczy, to wiara ta jest wyrazem poglądu, że On zawiera w sobie, że tak powiem, nieskończone

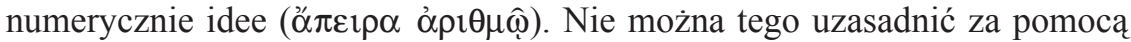
dowodu ( $\alpha \operatorname{\alpha } \delta \varepsilon \varepsilon \xi \xi v)$, lecz możemy tylko wierzyć, że tak godzi się sądzić o niestworzonym i wszelką naturę przewyższającym Umyśle"110.

Tekst ten potwierdza ostatecznie wszystko to, o czym na podstawie kontrowersyjnych fragmentów mówiliśmy wyżej. Bóg będąc wszechwiedzący,

${ }^{108}$ Tenże, Contra Celsum III 77, ed. M. Borret, SCh 136, Paris 1968, 174, thum. S. Kalinkowski: Orygenes, Przeciw Celsusowi, Warszawa 1986, 182.

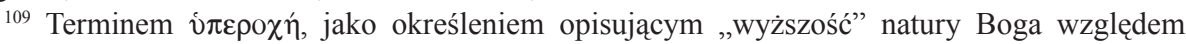
stworzenia, posługuje się Adamancjusz jeszcze w innym miejscu,. Por. tenże, Commentarius in Joannem XIII 25, 151-153, SCh 222, 114, gdzie mówi o przekraczającej wszelką miarę wzniosłość (

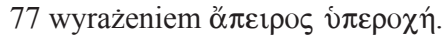

110 Tenże, Philocalia XXIII 20, ed. É. Junod, SCh 226, Paris 1976, 198, thum. K. Augustyniak: Orygenes, Filokalia, Warszawa 1979, 210 (thum. poprawione). 
obejmuje swą wiedzą wszystko, co dzieje się w stworzonym świecie, ale nie tylko. Jego wiedza nie ogranicza się jedynie do skończonego stworzenia ${ }^{111}$.

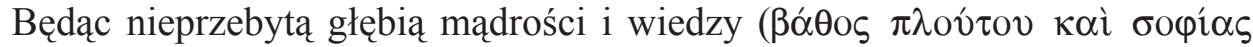

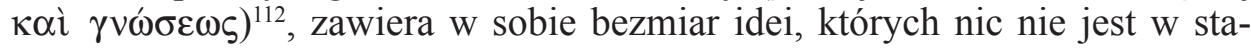
nie objąć czy przemierzyć. Stwierdzając, że idee Boskiego Intelektu są nie-

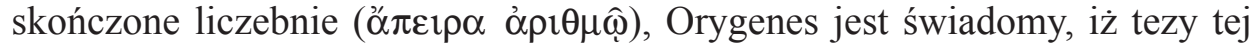

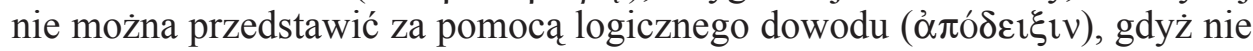
pozwala na to logika Arystotelesa. Nieskończoności wszakże ex definitione objąć nie można. A jednak istota Boga ją obejmuje. Taka jest bowiem wiara

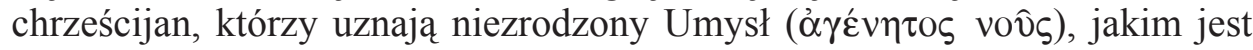
Bóg, za radykalnie różny od skończonego stworzenia, a więc nieskończony nie pod względem rozmiarów fizycznych, lecz pod względem nie mającej kresu aktywności intelektualnej ${ }^{113}$. Nieskończoność Boga dotyczy więc nie tylko czasowości (Bóg nie ma początku i końca), czy natury (Boża niecielesność zakłada brak jakichkolwiek granic), ale i wiedzy. Boska aktywność myślowa to coś więcej, o wiele więcej, niż tylko intelektualne, czy pojęciowe obejmowanie skończonego świata. Z faktu, iż Bóg stworzył skończony świat, co według Orygenesa potwierdza Pismo i logika Arystotelesa, nie wynika więc, iż natura Boga, czy też Jego moc i wiedza są w jakiś sposób ograniczone. Bóg bowiem wymyka się jakimkolwiek kategoriom fizycznym i metafizycznym, co wielokrotnie na kartach swoich pism podkreślał Adamancjusz.

${ }^{111}$ Por. tenże, Commentarius in Joannem I 34, 243-251; II 18, 124-128.

${ }_{112}$ Por. Rz 11, 33. Zob. Origenes, De principiis IV 3, 14.

${ }^{113}$ Autor komentarza do edycji krytycznej tekstu Filokalii (por. É. Junod, nota 3, w: Origène,

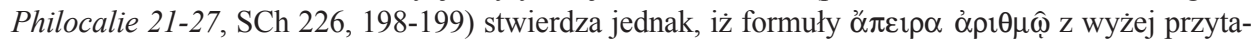
czanego tekstu nie należy tłumaczyć dosłownie. Orygenes bowiem nie wskazuje tu na nieskończona, lecz na znaczną (considérable) ilości rzeczy istniejących w Boskim Umyśle. Dla potwierdzenia swojej tezy Éric Junod odsyła do fragmentów, które już wyżej przytaczaliśmy, a które mówią o skończoności stworzenia. Błąd interpretacyjny, który popełnia komentator polega na niedostrzeżeniu, iż w omawianym fragmencie Orygenes mówi nie o bytach stworzonych, lecz o nieskończonych ideach Bożego Umysłu, który transcenduje wszelką naturę. Zbiór idei bytów świata stworzonego nie pokrywa się z wszystkim tym, co myśli Bóg, na co wskazują teksty Adamancjusza mówiące o niezgłębionej Mądrości Boga, na które się wyżej powoływaliśmy. Wyrażenie ő $\pi \varepsilon ı \rho \alpha ~ o ̉ \rho ı \theta \mu \hat{~ m o z ̇ n a ~}$ więc thumaczyć jako „nieskończenie liczebnie idee”. Dla potwierdzenia naszej tezy, przytoczymy jeszcze jeden fragment, w którym wiedza Boga zostaje porównana z wiedzą stworzeń. Por. Origenes, Selecta in Psalmos 144, PG 12, 1673A, tłum. własne: „Kontemplacja wszystkich bytów stworzo-

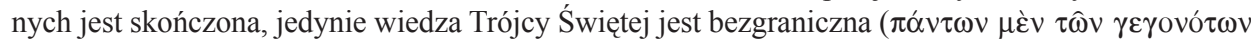

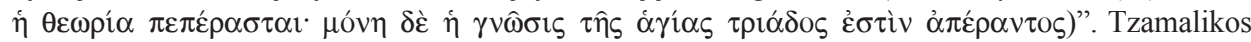

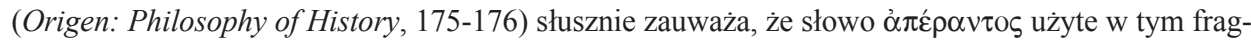
mencie na określenie wiedzy Trójcy, zawiera negację ( $\alpha$-privativum) tego samego rdzenia ( $\pi \varepsilon ́ p \alpha \varsigma$

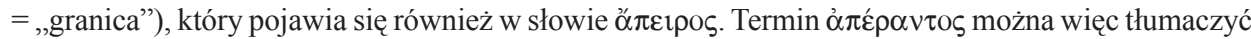
jako „nieposiadający granic”, „bezkresny”, ale i „nieskończony”. Choć autorstwo Orygenesa dotyczące zbioru fragmentów z Komentarza do Psalmów jest niekiedy kwestionowane, to z pewnością pochodzą one przynajmniej z kręgu jego uczniów, co i tak sprzeciwia się tezie Junoda, który twierdzi, iż wśród myślicieli z Aleksandrii panował aksjomat, iż Bóg nie może posiadać nieskończonej wiedzy. 
Na początku niniejszego tekstu przedstawiliśmy dość obszernie poglądy Filona i Klemensa z Aleksandrii na temat nieskończoności Boga, ukazując przy tym subtelną polemikę, jaką w tej kwestii prowadzili z filozofami greckimi. Było to konieczne, aby w dalszej części wykazać, iż Orygenes w swej doktrynie wcale nie odbiega od tego, co na temat Boga twierdzili jego żydowscy i chrześcijańscy poprzednicy. Mało tego, pokazaliśmy, iż syntetyczną definicję nieskończoności Boga, jaką znajdujemy w Kobiercach Klemensa, można by zrekonstruować również w oparciu o wypowiedzi zawarte w pismach Adamancjusza. Tak więc Bóg, również według Orygenesa, jest niecielesny, a więc i niepodzielny. Nie posiada wymiarów i, co się z tym wiąże, żadnej granicy. Jest bez kształtu i bez formy. Za nieskończonością Boga przemawia również fakt, iż jest on Dobrem, które bezgranicznie udziela się, obdarowując skończone stworzenia tym, co są w stanie przyjąć. Ponadto Bóg, będąc niezrodzonym Umysłem, jest też nie mającą początku ani kresu aktywnością myślenia. Z faktu, iż znajdujemy w pismach Orygenesa fragmenty, w których jest mowa o skończonej liczbie bytów stworzonych, nie wypływa wniosek, iż moc Boga jest skończona. Nie można wyprowadzić takiego wniosku nawet ze stwierdzenia, iż „to, co jest nieskończone, nie może być przez nic ogarnione". Teza ta, która pochodzi z rozważań Arystotelesa na temat nieskończoności, zostaje wykorzystana przez Adamancjusza, aby dowieść, iż to świat stworzony jest skończony, z czym nie zgadzało się wielu starożytnych, nie zaś w celu wykazania, iż moc Boga jest w jakiś sposób ograniczona. Świat ma więc swoje granice, początek i koniec - dlatego jest obejmowalny i poznawalny, zarówno przez Boga, jak i w jakiejś mierze przez człowieka. Przyjęcie poglądu, iż świat jest nieskończony, zakładałoby - według Orygenesa - zgodę na istnienie drugiego, obok Boga, nieskończonego absolutu, którego nic, nawet sam Bóg nie byłby w stanie ogarnąć. Prowadziłoby do absurdalnego wniosku, iż Bóg nie jest w stanie zapanować nad tym, co sam stworzył i poznać to, co jest jego dziełem. Nieskończoność jest bowiem tym, co się wymyka jakiemukolwiek objęciu, czy to fizycznemu, czy intelektualnemu. Logiczne konsekwencje hipotezy o nieskończonym świecie implikowałyby więc, według myśliciela z Aleksandrii, bezbożny i niezgodny z objawieniem obraz Boga. To właśnie Bóg swoją mocą obejmuje wszystko, a sam przez nic nie jest objęty. Ten ostatni pogląd zostaje jasno wyrażony zarówno w pismach Filona i Klemensa, i to właśnie w kontekście ich rozważań nad nieskończonością Boga, jak i w tekstach Orygenesa.

Bóg Adamancjusza jest więc nieskończony, nie tylko w aspekcie czasowym, na co jeszcze zgadza się wielu historyków idei, ale i pod względem natury, mocy i wiedzy. Potwierdzają to liczne wypowiedzi Orygenesa w tym względzie. Chociaż nie we wszystkich wprawdzie pojawia się słowo „nieskończoność”, czy „nieskończony” (ó $\pi \varepsilon \imath \rho o v)$, to jednak sam kontekst wyraźnie na to wskazuje. Jest tak choćby w przypadku intelektualnego przemierzania głębi 
mądrości i wiedzy Boga, którego podejmuje się człowiek wspomagany łaską. Choć po długich wysiłkach - twierdzi Adamancjusz - którym musi towarzyszyć wiara i praktyka cnót, ludzki intelekt jest w stanie dojść do poznania pewnych prawd dotyczących Boga, to jednak każde zrozumienie jakiejś tajemnicy prowadzi ku kolejnej, tak iż proces poznawczy nigdy nie będzie miał kresu. Dzieje się tak właśnie dlatego, iż Orygenes, podobnie jak Filon i Klemens uważają, iż Boża Mądrość jest nieskończona, a nieskończoność nigdy nie będzie mogła być objęta przez coś skończonego.

Ponadto, w tekstach Orygenesa zachowanych w języku greckim, znaj-

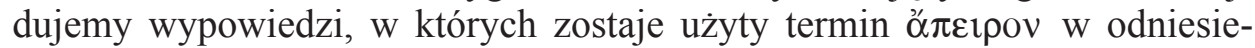
niu do Boga. Myśl w nich zawarta zaprzecza temu, czego dowiadujemy się z fragmentów zachowanych u cesarza Justyniana, w jego Liście do Menasa, a mianowicie, że moc Boga jest skończona. Chociaż sami badacze i autorzy wydań krytycznych dzieł Orygenesa, stwierdzają, iż fragmenty pochodzące od Justyniana są niekiedy niezrozumiałe lub mało wiarygodne, paradoksalnie przyznają rację tezom w nich zawartym. $\mathrm{Z}$ naszej analizy fragmentów paralelnych, znajdujących się w łacińskim tłumaczeniu Rufina, jak i na podstawie innych wypowiedzi Orygenesa, pojawiających się w tekstach zachowanych w języku greckim, wynika jednak, iż Bóg jest według niego nieskończony. Jego niecielesna natura nie ma granic; Jego niewyczerpana moc dobroczynna przewyższa możliwości przyjmujących ją stworzeń; Jego wiedza natomiast obejmuje nie tylko świat stworzony, lecz jest nieprzebytym bogactwem idei i tajemnic Bożej Mądrości. Tłumaczenie Rufina w tym względzie wydaje się więc bardziej oddawać myśl Orygenesa, niż greckie fragmenty zawarte w pismach jego adwersarzy.

W konkluzji naszego artykułu możemy więc stwierdzić, że nie tylko fragmenty pochodzące od starożytnych krytyków doktryny Adamancjusza wydają się przypisywać obce mu poglądy na temat skończoności Boga, ale - i to jest zasadniczy wniosek naszych badań - doktryna o nieskończoności Boga była obecna w myśli chrześcijańskiej od samych jej początków. To właśnie filozoficzna refleksja nad prawdami objawionymi doprowadziła do powstania pozytywnie rozumianego pojęcia nieskończoności. Bóg działający w historii narodu wybranego, Bóg troszczący się o każdego poszczególnego człowieka, a zarazem Bóg transcendentny, wszechmocny i wszechwiedzący, nie może być Bogiem skończonym, czyli doskonale zamkniętym w swym szczęściu, jak postulował Arystoteles. Pierwszym, który podjął refleksję w tej kwestii był żydowski myśliciel Filon z Aleksandrii. Po nim, rozwinął ją Klemens Aleksandryjski i wreszcie sam Orygenes. Należy tutaj dodać, że była ona obecna, o czym nie wspomnieliśmy, również u innych myślicieli chrześcijańskich, jak chociażby u Nowacjana ${ }^{114}$, współczesnego Orygenesowi, choć żyjącego W zachodniej części Imperium. W związku z powyższym rodzi się kolejna konkluzja, którą pozostawiamy na razie jako hipotezę: to Plotyn zbudował

${ }^{114}$ Por. Novatianus, De Trinitate 4, 25. 
swą doktrynę o nieskończonym Jednie w oparciu o osiągnięcia myślicieli żydowskich i chrześcijańskich, a nie na odwrót. Hipoteza ta jednak domaga się jeszcze dalszych badań historycznych i filologicznych.

\section{THE INFINITENESS OF GOD IN ORIGEN: A GREAT MISUNDERSTANDING}

\section{(Summary)}

Many historians of ideas - philosophers and theologians - believe that the first thinker to introduce the concept of a positive understanding of the infiniteness of God was Plotinus. In Greek philosophy, however, something infinite was understood as "unfinished" and therefore "imperfect". All the same, according to many scholars, Christianity took the concept of the infiniteness of God precisely from the founder of neo-Platonism. One of the reasons for which researchers of the doctrines of the ancient world persist in this thesis even today is the fact that, in the writings of Origen - who lived at the time of Plotinus - we find the expressions which might give readers the impression that God's power is finite, since God brought into existence a finite number of created beings. This article argues that this widely-held interpretation is wrong. Philo and Clement, a Jewish and a Christian thinker, both of Alexandria - from whose doctrines Origen borrowed abundantly - wrote of an infinite God before Origen did. In the surviving works of Origen, moreover, he nowhere states explicitly that God's power is finite, although it is true that, according to him, God created a finite number of creatures. The controversial thesis of a finite God is found only in fragments written by ancient critics of Origen's teaching. A detailed analysis of Origen's own original pronouncements on the nature, power and knowledge of God leads one to the conclusion that the fragments that have led many historians of ideas into confusion, either do not represent the views of Origen himself or present Origen's teachings inaccurately. Moreover, in Origen's surviving Greek writings, we find the term ó $\pi \varepsilon \iota \rho \circ v$ used in reference to God. This is precisely the term used by Greek philosophers to designate infinity. We may posit, then, that the concept of the infiniteness of God, positively understood, was born of the encounter of Greek philosophy with the Bible - that is, with the Jewish and Christian doctrines of the first centuries of the common era. Origen, who came slightly later, continued the thought of his predecessors and does not contradict them anywhere in his surviving works. What remains to be examined is the question of whether Plotinus himself made use of the work of Jewish and Christian thinkers in forming his doctrine of an infinite God, rather than those thinkers leaning on Plotinus, as is usually assumed.

Key words: the infiniteness of God, the power of God, the knowledge of God, patristic philosophy, Origen, Philo of Alexandria, Clement of Alexandria, the influence of Greek philosophy on Christianity, Plato, Aristotle, Plotinus. 
Slowa kluczowe: nieskończoność Boga, moc Boga, wiedza Boga, filozofia patrystyczna, Orygenes, Filon z Aleksandrii, Klemens z Aleksandrii, wpływ greckiej filozofii na chrześcijaństwo, Platon, Arystoteles, Plotyn.

\section{BIBLIOGRAFIA}

\section{Źródła}

Aristoteles, Physica, Metaphysica, Topica, De anima, ed. I. Bekker: Aristotelis opera edidit Academia Regia Borussica, vol. 1-2, Berlin 1831, thum. K. Leśniak: Arystoteles, Zachęta do filozofii. Fizyka, Warszawa 2010, A. Krąpiec - A. Maryniarczyk: Arystoteles, Metafizyka, t. 1-2, Lublin 1996.

Clemens Alexandrinus, Paedagogus, ed. O. Stählin, GCS 12, Leipzig 1905.

Clemens Alexandrinus, Stromata, ed. O. Stählin, GCS 15, Leipzig 1906, GCS 17, Leipzig 1909, thum. J. Niemirska-Pliszczyńska: Klemens Aleksandryjski, Kobierce zapisków filozoficznych dotyczacych prawdziwej wiedzy, t. 1-2, Warszawa 1994.

Irenaeus, Adversus haereses, ed. A. Rousseau - L. Doutreleau, t. 2: Livre I, SCh 264, Paris 1979.

Origenes, Commentarius in Joannem, ed. C. Blanc, SCh 120, Paris 1966, SCh 157, Paris 1970, SCh 222, Paris 1975, SCh 290, Paris 1982, SCh 385, Paris 1992, tłum. S. Kalinkowski: Orygenes, Komentarz do Ewangelii wedlug św. Jana, ŹMT 27, Kraków 2003.

Origenes, Commentarius in Matthaeum, ed. E. Klostermann - E. Benz, GCS 40, Leipzig 1935, thum. K. Augustyniak: Orygenes, Komentarz do Ewangelii wedlug św. Mateusza, ŹMT 10, Kraków 1998.

Origenes, Contra Celsum, ed. M. Borret, SCh 132, Paris 1967, SCh 136, Paris 1968, SCh 147, Paris 1969, SCh 150, Paris 1969, thum. S. Kalinkowski: Orygenes, Przeciw Celsusowi, Warszawa 1986.

Origenes, De oratione, ed. P. Koetschau, GCS 3, Leipzig 1899.

Origenes, De principiis, ed. H. Crouzel - M. Simonetti, SCh 252, Paris 1978, SCh 253, Paris 1978, SCh 268, Paris 1980, thum. S. Kalinkowski: Orygenes, O zasadach, ŹMT 1, Kraków 1996.

Origenes, Philocalia, ed. É. Junod, SCh 226, Paris 1976, 198, thum. K. Augustyniak: Orygenes, Filokalia, Warszawa 1979.

Origenes, Selecta in Psalmos, PG 12, 1053-1686.

Philo Alexandrinus, Opera quae supersunt, ed. L. Cohn - P. Wendland - S. Peiter, vol. 1-6, Berlin 1896-1915, thum. L. Joachimowicz: Filon Aleksandryjski, Pisma, t. 1, Warszawa 1986, S. Kalinkowski: Filon Aleksandryjski, Pisma, t. 2, Kraków 1994.

Plato, Parmenides, ed. A. Hermann: Plato's Parmenides. Text, Translation \& Introductory Essay, Las Vegas - Zurich - Athens 2010, thum. W. Witwicki: Platon, Dialogi, t. 2, Kęty 2005.

Plato, Respublica, ed. J. Adam: The Republic of Plato, vol. 1-2, Cambridge 1902.

Plato, Timaeus, ed. R.D. Archer-Hind: The Timaeus of Plato, London 1888.

\section{Opracowania}

Baron A., Neoplatońska idea Boga a ewangelizacja. Analiza anonimowego Komentarza do „Parmenidesa” Platona na tle myśli plotyńsko-porfiriańskiej, Kraków 2005.

BIGG C., The Christian Platonists of Alexandria. Eight Lectures Preached Before the University of Oxford in the Year 1886, Oxford 1886. 
Calabi F., Conoscibilità e inconoscibilità di Dio in Filone di Alessandria, w: Arrhetos Theos. L'ineffabilità del primo principio nel medio platonismo, ed. F. Calabi, Pisa 2002, 35-54.

Calabi F., God's Acting, Man's Acting. Tradition and Philosophy in Philo of Alexandria, Leiden 2008.

Choufrine A., Gnosis, Theophany, Theosis. Studies in Clement of Alexandria's Appropriation of His Background, New York 2002.

Edwards M., Christians and the „Parmenides”, w: Plato's „Parmenides” and its Heritage, vol. 2: Its Reception in Neoplatonic, Jewish, and Christian Texts, ed. J.D. Turner - K. Corrigan, Atlanta 2010, 189-198.

Mondolfo R., L'infinito nel pensiero dell'antichità classica, Milano 2012.

Moreschini C., I Padri cappadoci. Storia, letteratura, teologia, Roma 2008.

Moreschini C., Storia del pensiero cristiano tardo-antico, Milano 2013.

Moreschini C., Storia della filosofia patristica, Brescia 2005.

Mrugalski D., Il Dio trascendente nella filosofia alessandrina giudaica e cristiana. Filone e Clemente, Roma 2013.

Osborn E., Clement of Alexandria, Cambridge 2005.

Przyszychowska M., Wstęp, w: Grzegorz z Nyssy, O stworzeniu człowieka, ŹMT 39, Kraków 2006, 5-38.

Radice R., Una proposta di lettura della „Fisica” di Aristotele, w: Aristotele, Fisica. Testo greco a fronte, ed. R. Radice, Milano 2011, 5-103.

ReAle G. - RAdice R., La genesi e la natura della filosofia mosaica. Struttura, metodo e fondamenti del pensiero filosofico e teologico di Filone di Alessandria, w: Filone di Alessandria, Tutti i trattati del commento allegorico alla Bibbia. Testo greco a fronte, ed. R. Radice, Milano 2005, XV-CLVI.

Reale G., Historia filozofii starożytnej, t. 4: Szkoły epoki cesarstwa, thum. E.I. Zieliński, Lublin 1999.

Reale G., Historia filozofii starożytnej, t. 5: Stownik, indeksy i bibliografia, thum. E.I. Zieliński, Lublin 2002.

Runia D.T., Early Alexandrian Theology and Plato's „Parmenides”, w: Plato's „Parmenides" and its Heritage, vol. 2: Its Reception in Neoplatonic, Jewish, and Christian Texts, ed. J.D. Turner - K. Corrigan, Atlanta 2010, 175-187.

Simonetti M., Dio (Padre), w: Origene. Dizionario. La cultura, il pensiero, le opere, ed. A. Monaci Castagno, Roma 2000, 118-124.

Simonetti M., Introduzione, w: Origene, I principi, Torino 1979, 9-92.

Tzamalikos P., Origen: Cosmology and Ontology of Time, Leiden 2006.

Tzamalikos P., Origen: Philosophy of History \& Eschatology, Leiden 2007.

Whittaker J., Philological Comments on the Neoplatonic Notion of Infinity, w: The Significance of Neoplatonism, ed. R. Harris, Norfolk 1976, 155-172. 
